\title{
A formação de tradutoras e tradutores de línguas orais (Português/Inglês) no Brasil: um estudo das diferentes concepções curriculares'
}

\author{
Andréia Guerini \\ andreia.guerini@gmail.com \\ Universidade Federal de Santa Catarina, Florianópolis, Brasil
}

\author{
Germana Henriques Pereira \\ germanahp@gmail.com \\ Universidade de Brasília, Brasília, Brasil
}

\begin{abstract}
Resumo
A formação de tradutores e tradutoras de línguas orais em nível de graduação data no Brasil do final da década de 1960. Atualmente, há aproximadamente 30 cursos de graduação que se destinam ao ensino de Tradução espalhados pelo território brasileiro, com maior concentração no estado de São Paulo, em sua maioria ofertados por instituições privadas (Costa, 2018). O currículo pode ser entendido como um conjunto constituído por conhecimentos considerados válidos, resultado de diferentes concepções sociais e tradições (Goodson, 2013). Tal fato se mostra verdade no Brasil, vistas as diferentes concepções curriculares destinadas à formação de tradutoras e tradutores de línguas orais no par linguístico Inglês/Português em nível de graduação. Esse artigo tem por objetivo apresentar uma discussão relativa à concepção curricular de programas de graduação que têm por finalidade a formação de tradutoras e tradutores nas Instituições de Ensino Superior (IES) públicas e privadas brasileiras, fundamentando-se na análise documental (Scott, 2006; Cohen; Manion; Morrison, 2007), respaldada pela abordagem qualiquantitativa (Lamoureux, 2003; Cohen; Manion; Morrison, 2007; Thouin,
\end{abstract}

1 Este artigo fundamenta-se em grande parte na pesquisa de doutorado de Patrícia Rodrigues Costa, intitulada $A$ formação de tradutores em instituições de educação superior públicas brasileiras: uma análise documental (2018), desenvolvida entre 2014 e 2018 na Universidade Federal de Santa Catarina em cooperação com a Université de Montréal, Canadá. Esta pesquisa foi orientada pela Profa. Dra. Andréia Guerini (UfSC), coorientada pela Profa. Dra. Germana Henriques Pereira (UnB) e pelo Prof. Dr. Álvaro Echeverri (UMontréal) e financiada pela Coordenação de Aperfeiçoamento de Pessoal de Nível Superior (CAPES) por meio de bolsas destinadas ao financiamento de pesquisas de pós-graduação (CAPES/DS e CAPES/PSDE). 
2014). Pudemos verificar distinções quanto às concepções curriculares entre os bacharelados ofertados por Instituições de Ensino Superior públicas e privadas.

Palavras-chave: Formação de tradutores e tradutoras no Brasil, história da tradução, teoria curricular, concepção curricular.

\title{
The Education of Translators of Oral Languages (Brazilian Portuguese/English) in Brazil: a Study of the Diverse Curriculum Designs
}

\begin{abstract}
In Brazil, the education of translators of oral languages at undergraduate level dates back to the late 1960s. Nowadays, there are approximately 30 undergraduate courses devoted to Translation teaching throughout Brazil, being most of these courses held by private institutions with a higher concentration in the state of São Paulo (Costa, 2018). According to Ivor Goodson (2013), curriculum design consists of knowledge that is considered valid, being the result of different social conceptions and traditions. This can be considered a fact in Brazil, since it is possible to observe different curriculum designs aimed at translator education of oral languages (English/Portuguese) at undergraduate level. The main goal of this paper is to discuss the curriculum design of Translation undergraduate programs at Brazilian Higher Education Institutions, both public and private, based on a documentary analysis (Scott, 2006; Cohen; Manion; Morrison, 2007) supported by a qualitative-quantitative approach (Lamoureux, 2003; Cohen; Manion; Morrison, 2007; Thouin, 2014). We were able to verify differences regarding the curriculum designs of the undergraduate courses offered by public and private Higher Education Institutions.
\end{abstract}

Keywords: Translator education in Brazil, translation history, curriculum theory, curriculum design.

\section{La formation des traducteurs et des traductrices de langues orales (portugais/ anglais) au Brésil : une étude des différents conceptions curriculaires}

\section{Résumé}

Au Brésil, la formation des traductrices et traducteurs de langues orales à l'enseignement supérieur date de la fin des années 1960. À l'heure actuelle, il y a environ 30 cours consacrés à l'enseignement de la traduction au niveau universitaire. Ils s'étendent à l'ensemble du territoire brésilien, étant plus concentrés dans la province de São Paulo, dont la plupart sont offerts par des institutions privées (Costa, 2018). Le curriculum peut être compris comme un ensemble de connaissances considérées valables, résultant des traditions et de différentes conceptions sociales (Goodson, 2013). Ceci se révèle vrai au Brésil, étant donné les différentes conceptions curriculaires destinées à la formation des traductrices et traducteurs de langues orales dans le pair linguistique anglais/portugais à l'enseignement supérieur. Cet article a pour but de présenter une discussion relative à la conception curriculaire des programmes d'études supérieures qui visent à la formation des traductrices et traducteurs dans des institutions brésiliennes d'enseignement supérieur (IES) publiques et privées. Notre étude s'appuie sur l'analyse documentaire (Scott, 2006 ; Cohen ; Manion ; Morrison, 2007), soutenue par l'approche quali-quantitative (Lamoureux, 2003 ; Cohen ; Manion ; Morrison, 2007 ; Thouin, 2014). Nous avons pu vérifier des différences par rapport aux conceptions curriculaires parmi les cours dans la formation du premier cycle (bacharelados) offerts par des institutions d'enseignement supérieur publiques et privées.

Mots-clés: Formation des traductrices et traducteurs au Brésil, histoire de la traduction, théorie curriculaire, conception curriculaire. 


\section{Introdução}

A formação de tradutoras e tradutores em ambiente universitário americano e europeu data do século xIx: na Argentina, de 1868, na Alemanha, de 1887, e na China, de 1898 (Harris, 1997; Nord, 1991). Somente no século xx houve uma real expansão de graduações destinadas à formação em Tradução, com destaque para Europa e América do Norte. Em 1936, foram criados cursos na Ruprecht-Karls-Universität Heidelberg, na Alemanha (Harris, 1997) e na University of Ottawa e diversos outros foram criados no contexto pré e pós Segunda Guerra Mundial (1939 - 1945). Na América Latina (Hagel, 1990), tais cursos só começaram a surgir algumas décadas mais tarde, a saber: Uruguai, 1954; México, 1966; Cuba, 1968; Porto Rico, 1970; Chile, 1971; Peru e Venezuela, 1974; Equador, 1983. No Brasil, a história da formação de tradutoras e tradutores em nível universitário começa a se delinear no final da década de 1960 devido a mudanças na legislação educacional (Frota; Britto; Martins, 2012). Assim, pode-se dizer que a tradição brasileira em formar tradutoras e tradutores se iniciou em 1969, ano da criação do primeiro curso destinado a tal formação na Pontifícia Universidade Católica do Rio de Janeiro (Puc-Rio) e que foi seguido pela proposta de cursos de bacharelado em Letras com habilitação em Tradução.

Conforme Pym (1998), a criação de cursos destinados à formação de tradutores e tradutoras separados daqueles que visavam à formação de professores de línguas estrangeiras, ganhou força no continente europeu e americano somente no final do século xx. Além disso, segundo esse estudioso, é a partir da década de 1980 que a necessidade social de tradutoras e tradutores e de intérpretes passou a ser ressaltada pelos discursos institucionais, o que auxiliou na expansão de cursos de Tradução pelo mundo. No Brasil, chama atenção o fato de que somente cerca de 40 anos após a criação dos cursos de Letras com habilitação em Tradução os primeiros Bacharelados ${ }^{2}$ em Tradução ${ }^{3}$, desvinculados das graduações em Letras, foram propostos e criados, a saber, na Universidade Federal de Uberlândia (UFU) e na Universidade Federal da Paraíba (UFPB). Destacamos ainda a criação do primeiro programa de pós-graduação (PPG) stricto sensu em Estudos da Tradução na Universidade Federal de Santa Catarina em 2003, que abriu caminhos para a criação de PPGS - POSTRAD na Universidade de Brasília (2011), Tradusp ${ }^{4}$ na Universidade de São Paulo (2011) e POET na Universidade Federal do Ceará (2014) ,- e, consequentemente, ampliou as possibilidades para pesquisas sobre Tradução e fortaleceu este campo de pesquisa.

A partir dessas considerações, este artigo tem por objetivo apresentar um retrato da formação de tradutoras e tradutores de língua orais em nível de graduação no Brasil. Para que tal representação seja possível, evidenciaremos, em um

2 No Brasil, a formação universitária inicia-se em nível de graduação, a qual pode ser dividida em cursos de bacharelado, licenciatura e tecnológicos. Esses cursos se diferenciam pela duração, foco e tipo de diploma. O bacharelado proporciona uma formação mais generalista, tem duração de três a seis anos e confere o grau de bacharel. A licenciatura visa à formação de professores, com duração entre três e cinco anos, e confere o grau de licenciado. Os cursos tecnológicos ofertam disciplinas mais práticas e voltadas para o mercado de trabalho, duram entre dois e três anos e conferem o grau de tecnólogo.

3 A formação de tradutoras e tradutores se deu, inicialmente, por razões de legislação educacional, ligada diretamente aos cursos de Letras, razão pela qual os primeiros cursos partiam do currículo mínimo de Letras. Somente anos mais tarde essa vinculação deixou de ser obrigatória (Costa, 2018).

4 Depois da última avaliação nacional, realizada pela CAPES em 2016, ficou decidido que o Tradusp seria fundido com outros programas da área de Linguística e Literatura da Universidade de São Paulo. 
primeiro momento, dados históricos importantes para a implantação dos primeiros cursos de graduação com vistas à formação de tradutoras e tradutores no Brasil, bem como aqueles relacionados à expansão de tal formação no território brasileiro. Em um segundo momento, descreveremos o método utilizado por Costa (2018) para a análise de documentos - textos oficiais nacionais, institucionais e publicações, nos quais estão inseridos os currículos -, o qual possibilitou a verificação das singularidades da formação de tradutoras e tradutores no Brasil. Em um terceiro momento, apresentaremos particularidades quanto à formação de tradutoras e tradutores no Brasil em nível de graduação.

\section{A formação de tradutores e tradutoras em cursos de nível superior: aspectos históricos}

A princípio, poderíamos pensar que a criação de cursos de graduação em Tradução no Brasil foi tardia em relação ao restante do continente americano e europeu, por ter se iniciado apenas no final da década de 1960. Contudo, devemos lembrar que mesmo com a criação de cursos no final do século xIx, poucos eram os que se constituíam como cursos de Tradução propriamente ditos, e o da Argentina está até hoje vinculado à Faculdade de Direito. Um movimento mais consistente de abertura de cursos de Tradução em universidades ocorreu apenas no contexto pré e pós II Guerra Mundial, caracterizando uma primeira expansão somente nas décadas de 1930 e 1940. Ademais, os Estudos da Tradução, como campo de estudo acadêmico, só se estabeleceram em torno de 30 anos mais tarde, o que atenua um suposto atraso do Brasil em criar seus primeiros cursos superiores de tradução.

Antes mesmo do estabelecimento da área dos Estudos da Tradução em nível acadêmico, as discussões acerca da formação de tradutoras e tradutores já tinham começado a ganhar fôlego, especialmente a partir da instituição da Conférence Internationale Permanente de Directeurs d'Instituts Universitaires pour la Formation de Traducteurs et d'Interprètes (CIUTI), em 1960, que reuniu diretores de escolas de tradução e interpretação das Universidades de Genebra, Heidelberg, Sarrebruck, Mayence, Paris-Sorbonne e Trieste. Durante a reunião em Bâle, Suíça, esses diretores discutiram acerca dos problemas inerentes à formação de tradutores e de intérpretes com vistas a melhorar a qualidade de seu ensino e defenderam a especificidade de tais formações, que em sua maioria eram ofertadas por departamentos de Linguística. Dezesseis anos mais tarde, em 1976, a Organização das Nações Unidas publicou a Recommandation sur la protection juridique des traducteurs et des traductions et sur les moyens pratiques d'améliorer la condition des traducteurs, conhecida por Recomendação de Nairobi (Unesco, 1976). A ciuti, que à época já tinha como membros instituições não-europeias, passou a seguir e endossar a Recomendação de Nairobi, na qual a formação e a condição de trabalho de tradutoras e tradutores são colocadas em pauta, como pode ser constatado a seguir:

11. Os Estados-Membros devem reconhecer o princípio segundo o qual a Tradução é uma disciplina autônoma cujo ensino deve ser distinto do ensino exclusivamente linguístico e que requer uma formação especializada. Devem encorajar a criação, em particular com organizações ou associações profissionais de tradutores, das universidades ou de outros estabelecimentos de ensino, de cursos de redação destinados aos tradutores, bem como a instituição de seminários ou estágios práticos. Deve-se reconhecer também a utilidade, para os tradutores, de poder se beneficiar de estágios de formação continuada $^{5}$. (Unesco, 1976, s.p).

5 11. Les États membres devraient reconnaître le principe selon lequel la traduction est une discipline autonome 
Outro aspecto que nos permite afirmar que a criação de cursos de graduação destinados à formação de tradutoras e tradutores no Brasil não se deu tão tardiamente é o fato de que mesmo ofertando cursos de Tradução desde a década de 1930, o Canadá, país com um dos cursos mais antigos e com forte tradição na formação de tradutoras e tradutores, somente começou a multiplicar a oferta de cursos em seu território anos mais tarde. Essa expansão, mais de 30 anos após a criação do primeiro curso, na Universidade de Ottawa, em 1936, deu-se em razão de leis que defendiam o status das línguas oficiais e que resultaram no aumento de demandas de mercado devido à necessidade de publicações bilíngues (FIOLA, 2003, p. 34 - 36). Com esse pano de fundo, podemos ter uma outra visão acerca da suposta "oferta tardia" quanto à formação de tradutoras e tradutores no Brasil.

Segundo relatado por Maria Paula Frota, Paulo Henriques Britto e Marcia do Amaral Peixoto Martins (2012, p. 1) em número especial do periódico Tradução \& Revista, dedicado a Maria Candida Bordenave, pioneira no ensino de Tradução no Brasil, foi a partir da promulgação da Lei $\mathrm{n}^{\circ} 5.540$, de 28 de novembro de 1968 (Brasil, 1968), conhecida como Lei de Diretrizes e Bases (LDB) ou Reforma Universitária de 1968, que a formação de tradutoras e tradutores teve seu pontapé inicial. Essa lei compreendia a concepção da educação como auxiliar direta no desenvolvimento do Brasil

dont l'enseignement doit être distinct de l'enseignement exclusivement linguistique et qui requiert une formation spécialisée. Ils devraient encourager la création, en liaison notamment avec les organisations ou associations professionnelles de traducteurs, des universités ou d'autres établissements d'enseignement, de cours de rédaction destinés aux traducteurs ainsi que l'institution de séminaires ou de stages pratiques. Il conviendrait aussi de reconnaitre l'utilité, pour les traducteurs, de pouvoir bénéficier de stages de formation continue
(Souza, 2016). Como consequência das propostas dessa reforma, houve o crescimento do setor privado, bem como a fragmentação de graduações em cursos de menor duração que atendiam às demandas do mercado de trabalho (Palma Filho, 2010).

Dos 59 artigos inscritos nessa lei, podemos ressaltar três (artigos 18, 23 e 26) que viabilizaram a instituição de graduações destinadas à formação de tradutoras e tradutores, uma vez que passou a ser possível criar cursos superiores não-tradicionais, isto é, não destinados, por exemplo, à formação de professoras e professores. Permitiu-se, assim, a criação de bacharelados a partir do currículo mínimo do curso de Letras - ressaltando-se que a obrigatoriedade legal de adesão a um currículo mínimo cessou em 1996. Além disso, foi possível a criação de cursos destinados a profissões ainda não regulamentadas ${ }^{6}$.

Neste contexto, em 1969 foi criado o primeiro bacharelado em Letras destinado à formação de revisor-tradutor-intérprete na Pontifícia Universidade Católica do Rio de Janeiro (PUC-Rio) (Frota; Britto; Martins, 2012, p. 1), iniciando assim uma tradição no setor privado de ensino. Já os bacharelados em Letras com foco na formação em Tradução em instituições públicas só se tornaram reais a partir de 1973, ano da criação do curso da Universidade Federal do Rio Grande do Sul (UFRGS).

Como se vê, a tradição brasileira em formar profissionais da área da Tradução teve seu início durante a Ditadura Militar Brasileira

6 No Brasil, a profissão de tradutoras e tradutores foi reconhecida em 1988, mas ainda não é regulamentada, haja vista que não tem um conselho fiscalizador dos profissionais da área, tal como, por exemplo, a Ordem dos Advogados do Brasil (OAB) ou o Conselho Regional de Engenharia e Agronomia (CREA). 
(1964 -1985). Foi nesse período que diversas instituições públicas e privadas começaram a ofertar bacharelados em Letras-Tradução. Podemos dividir a história da formação de tradutoras e tradutores em quatro momentos já concluídos: (1) a Ditadura Militar Brasileira; (2) a Redemocratização do Brasil, os primeiros anos do período democrático brasileiro; (3) o governo Fernando Henrique Cardoso (1995-2003); (4) o governo Lula (2003-2011). Desses quatro momentos, destacam-se para o ensino superior público brasileiro, no contexto da formação de tradutoras e tradutores, a Ditadura Militar (1964-1985) e o governo Lula (2003-2011), como será explicitado adiante.

Dos 11 bacharelados em Letras-Tradução ou somente em Tradução ofertados em Instituições de Ensino Superior (IES) públicas, quatro foram criados durante a Ditadura Militar: o da Universidade Federal do Rio Grande do Sul (UFRGS), em 1973; o da Universidade Estadual Paulista "Júlio de Mesquita Filho" (Unesp), campus São José do Rio Preto, em 1978; o da Universidade de Brasília (UnB), em 1979; e o da Universidade Federal de Ouro Preto (UFOP), em 1980. É nesse período também que os três primeiros bacharelados em IEs privadas são criados: na Pontifícia Universidade Católica do Rio de Janeiro (PUC-Rio), em 1969; na Faculdade Ibero-Americana ${ }^{7}$ (FIA), em 1972; na Pontifícia Universidade Católica de São Paulo (PUC-SP), em 1977.

\footnotetext{
7 Inicialmente ofertado pela Faculdade Ibero-Americana (FIA), que anos mais tarde passou a ser denominada Centro Universitário Ibero-Americano (UNIBERO), o qual foi comprado em 2009 pelo grupo Anhanguera Educacional. O curso da FIA começou a funcionar somente em 1972, mesmo tendo sido a primeira instituição a requerer a criação do bacharelado destinado à formação de tradutoras e tradutores (Costa, 2018, p. 197 - 198).
}

Durante a transição da Ditadura Militar para o Estado democrático de Direito, período conhecido por Redemocratização, somente um bacharelado foi criado em IES pública, o da Universidade Federal de Juiz de Fora (UFJF), em 1987. Porém, é durante a redemocratização e os primeiros anos de democracia brasileira (governo José Sarney, de 1985 a 1990; governo Collor, de 1990 a 1992; e governo Itamar Franco, de 1992 a 1995) que seis bacharelados em Tradução são criados em IES privadas (ver Gráfico 2).

Segundo José Souza (2016), durante o governo de Fernando Henrique Cardoso (1995-2003), as universidades públicas sofreram sucateamento em razão dos cortes de verbas públicas e da ausência de concursos públicos para a contratação de docentes e técnicos-administrativos. Por outro lado, segundo ele, foi nesse governo que houve uma forte expansão da educação privada com verbas públicas. Assim, durante esse mandado, as IEs privadas multiplicam bacharelados em Letras-Tradução ou Letras-Tradução e Interpretação. Atualmente, dos 18 bacharelados ofertados por instituições privadas, seis foram criados neste período. Conforme Maria Paula Frota (2007, p. 142), a multiplicação de cursos de Tradução no setor privado pode ser justificada pela profissionalização do mercado a partir de 1996. Assim, enquanto foram criados seis bacharelados em IES privadas, somente um foi criado em IES pública, o da Universidade Federal do Paraná (UFPR), em 2001, denominado como Letras Ênfase em Estudos da Tradução.

O quarto momento da história da formação de tradutoras e tradutores no Brasil começa a se estabelecer a partir de 2003, durante o governo de Luiz Inácio Lula da Silva (2003 - 2011). Nesse governo foi estabelecido o Programa de Reestruturação e Expansão das Universidades Federais (REUNI), que possibi- 
litou a interiorização das universidades públicas federais por meio da abertura de novos campi e novas IEs, bem como a criação de cursos superiores e concursos públicos para a contratação de docentes. Deste modo, no contexto do REUNI foram criados quatro bacharelados destinados à formação de tradutoras e tradutores em IES públicas: Universidade Estadual de Maringá (UEM), em 2007; Universidade Federal da Paraíba (UFPB), em 2009; Universidade Federal de Uberlândia (UFU), em 2009; e Universidade Federal de Pelotas (ufrel), em 2010. Ainda no contexto do REUNI, as IES que já ofertavam bacharelados em Tradução ampliaram seus cursos, de modo que a Universidade de Brasília criou uma segunda graduação em 2009 em Letras-Tradução/Espanhol, no período noturno no período diurno é ofertado o curso de Letras-Tradução com habilitação em Inglês ou Francês -, e, a partir de 2013, a Universidade Federal de Juiz de Fora passou a ofertar, além da habilitação em Tradução-Inglês, as de Francês e de Latim. Foi também durante o REUNI que foram criados os primeiros Bacharelados em Tradução desvinculados dos cursos de Letras, na Universidade Federal da Paraíba e na Universidade Federal de Uberlândia.

Por fim, um quinto momento começa a se delinear. Em 2017 foi criado um bacharelado em Tradução em uma IEs privada, o da Faculdade Cultura Inglesa, e em 2018, fora do contexto do REUNI, foi criado um bacharelado em Tradução em IEs pública, o da Universidade Federal de Minas Gerais ${ }^{8}$ (UFMG).

8 Vale ressaltar que a história da UFMG com Tradução não é recente, uma vez que diversas são as pesquisas relacionadas aos Estudos da Tradução desenvolvidas no Programa de Pós-Graduação em Estudos Linguísticos (POSLIN) e disciplinas de Tradução já eram ofertadas nos cursos de graduação em Letras.
Nos gráficos 1 e 2, a seguir, podem-se verificar os anos de criação dos bacharelados em Tradução no Brasil, bem como identificar as particularidades políticas de cada período, sendo que em ambos a primeira IEs a figurar é aquela que criou o primeiro bacharelado no país, a Pontifícia Universidade Católica do Rio de Janeiro (PUC-Rio).

Após esse breve relato da história da formação de tradutores e tradutoras no Brasil, passaremos a descrever as particularidades desses bacharelados em Letras-Tradução e Tradução.

\section{Particularidades da formação de tradutoras e tradutores no Brasil}

A formação de tradutoras e tradutores no Brasil, como visto anteriormente, expandiu-se desde a data de criação do primeiro bacharelado em 1969. No entanto, essa expansão não se deu uniformemente em todo o país.

Dos 11 bacharelados públicos existentes atualmente, cinco estão localizados na região Sudeste (Universidade Federal de Ouro Preto - UfoP, Universidade Federal de Juiz de Fora UJFJ, Universidade Estadual Paulista "Júlio de Mesquita Filho" - Unesp, Universidade Federal de Uberlândia - UFU e Universidade Federal de Minas Gerais - UFMG), quatro na região Sul (Universidade Estadual de Maringá - UEM, Universidade Federal do Paraná - UfPR, Universidade Federal do Rio Grande do Sul - UFRGs e Universidade Federal de Pelotas - Ufpel), um na região Centro-Oeste (Universidade de Brasília - UnB) e um na região Nordeste (Universidade Federal da Paraíba - UFPB), sendo o estado de Minas Gerais aquele com maior quantidade de bacharelados em Letras/Tradução e/ou Tradução ofertados em IEs públicas no Brasil. Por outro lado, no que se refere aos 18 bacharelados de IES privadas, diversos são aqueles que ofertam tal formação em mais de 


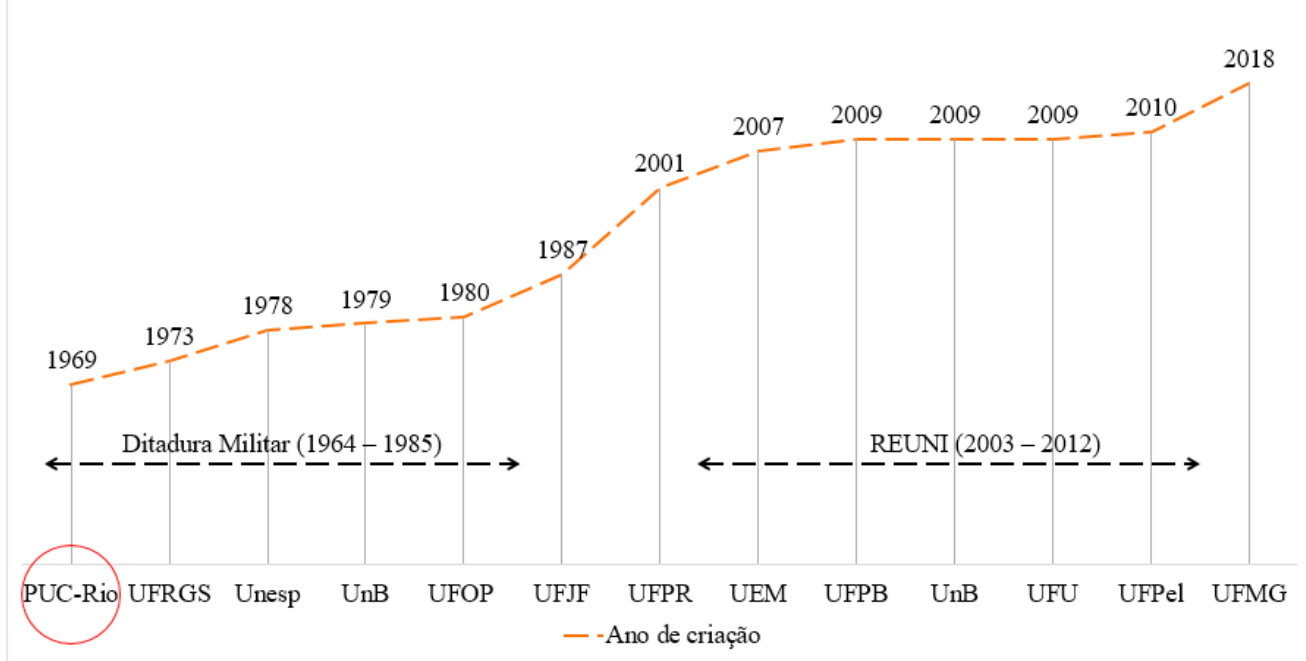

Gráfico 1. Ano de criação de graduações em Tradução em IEs públicas brasileiras.

Fonte: Costa (2018), com adaptações.

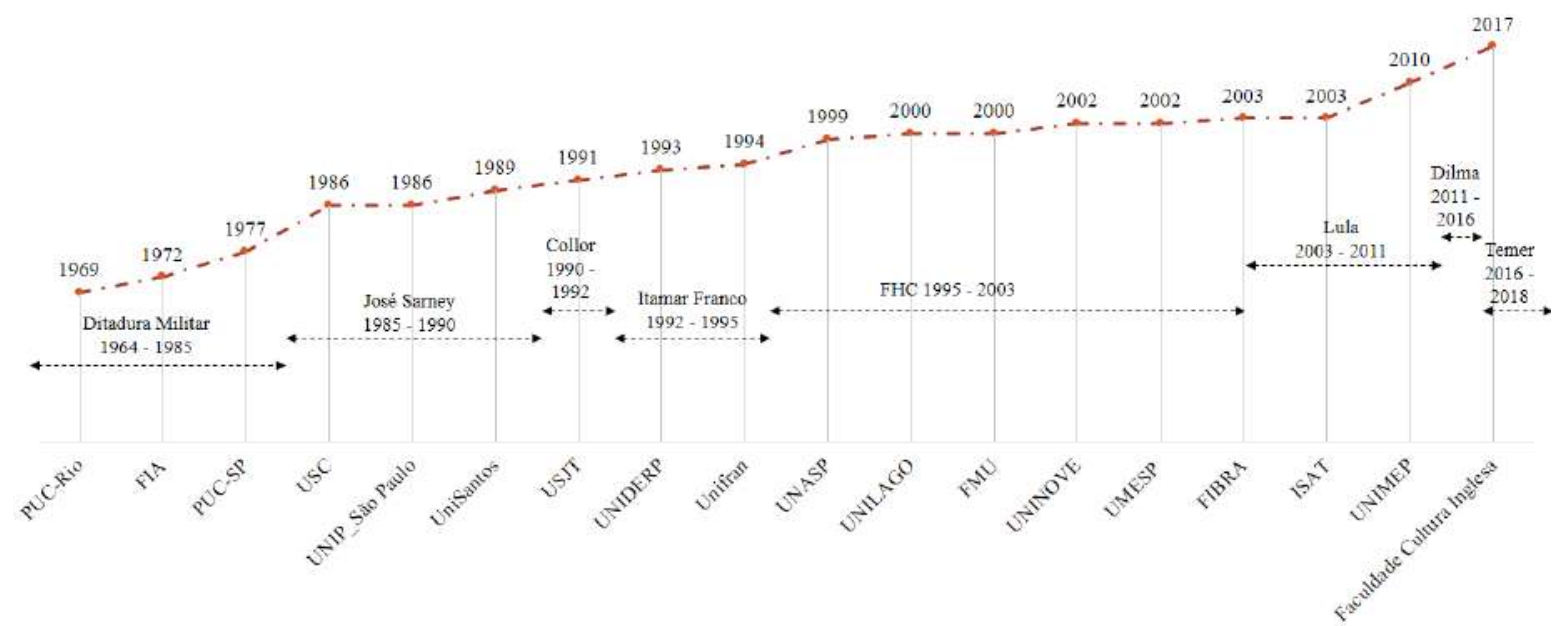

Gráfico 2. Ano de criação de graduações em Tradução em IEs privadas brasileiras.

Fonte: Costa (2018), com adaptações.

um campus, sendo que a região Sudeste destaca-se com a maior quantidade de campi que ofertam bacharelado em Letras/Tradução, os quais se concentram principalmente no estado de São Paulo. É a partir desse cenário que discutiremos questões relacionadas à concepção curricular dos bacharelados destinados à formação de tradutoras e tradutores.
Conforme Goodson (2013), a elaboração de currículos deve ser entendida como algo que vai além das matrizes curriculares dos cursos. Toda documentação proveniente do processo de elaboração curricular pode ser compreendida como a invenção de uma tradição e uma relação direta das relações sociais e de poder. A história curricular de cada curso permitiria 
explicar o papel das profissões perante a construção social do conhecimento (Goodson, 2013). O currículo seria, para ele, constituído por conhecimentos considerados válidos em um determinado momento da história, razão pela qual o currículo dos cursos deve ser alterado, atualizado de tempos em tempos. Assim, compreendemos que diferentes tradições podem coexistir, uma vez que não há uma Diretriz Curricular Nacional para o curso de Tradução no Brasil. Deste modo, podemos considerar diferentes tradições relacionadas à formação de tradução e tradutores no Brasil: (1) a das IEs pública vs. a das IES privadas; (2) a dos bacharelados em Letras/Tradução vs. a dos bacharelados em Tradução; e, até mesmo, (3) a dos bacharelados que formam tradutoras, tradutores e intérpretes vs. aquela dos bacharelados que formam somente tradutoras e tradutores.

Com vistas a caracterizar as particularidades da formação de tradutoras e tradutores no Brasil, segundo diferentes tradições, Costa (2018), em sua pesquisa de doutorado, elegeu realizar uma análise documental dos bacharelados ofertados em Instituições de Ensino Superior (IES) público, modelo que será seguido aqui. Assim, apresentaremos, de maneira resumida, os critérios desta análise e as particularidades verificadas no ensino público para, em segui$\mathrm{da}$, expormos dados relacionados aos bacharelados ofertados em IES privadas no Brasil.

\subsection{A pesquisa documental}

O método de pesquisa aqui utilizado foi o de um estudo descritivo e exploratório, não avaliativo, com procedimento técnico fundamentado na pesquisa documental (Scott, 2006; Cohen; Manion; Morrison, 2007), com base na análise de conteúdo e com a análise de dados respaldada pela abordagem qualiquantitativa (Lamoureux, 2003; Cohen; Manion; Mor- rison, 2007; Thouin, 2014). Destacamos que foram considerados documentos quaisquer textos que não tenham recebido tratamento analítico (Gil, 2008). Assim, foram analisados documentos - textos oficiais nacionais, institucionais e publicações científicas - que trouxessem informações sobre os programas de graduação em questão.

Sabemos que pesquisas relacionadas à Educação utilizam, em geral, métodos diversos - entrevistas, aplicação de questionários e observação em campo -, e que poucas são as que se utilizam da pesquisa documental, mesmo sendo esta uma das principais formas de pesquisa social, a qual inclui a pesquisa educacional (Scott, 2006; Cohen; Manion; Morrison, 2007). Esse fato pode ser justificado em parte pela dificuldade de acesso a documentos, seja da esfera pública, seja da privada. Além disso, é necessário que se analisem dados autênticos, que denotem credibilidade e que sejam representativos (Scott, 2006). Infelizmente, algumas IEs disponibilizam de maneira incompleta documentos relacionados aos seus programas de graduação, o que pode gerar lacunas no estudo ou impossibilitar a análise de dados.

Colocadas essas questões, e para que fosse possível a comparação, os bacharelados analisados foram aqueles que cumpriam os seguintes critérios:

1. Ter em seu título o termo Tradutor ou Tradução ${ }^{9}$

2. Ter por objetivo principal a formação de tradutoras e tradutores, e não de professoras e

9 Escolhemos analisar cursos que tenham o termo Tradutor ou Tradução em seu título, pois segundo as Diretrizes Curriculares Nacionais para o curso de Letras, os cursos de graduação em Letras também podem formar tradutoras e tradutores, mesmo que a concepção curricular não espelhe tal formação. 
professores de língua estrangeira ou pesquisadoras e pesquisadores em Tradução ${ }^{10}$;

3. Ter sido reconhecido pelo Ministério da Educação (MEC), o que implica turmas formadas;

4. Ter como par de línguas Português/Inglês ${ }^{11}$.

Conforme Pym (1998), devem-se utilizar critérios nem muito restritos, nem muito amplos, com vistas à construção de um corpus de pesquisa, para que não seja necessário listar todos os cursos vinculados aos departamentos de língua, de modo que a pesquisa se torne realista e representativa. Com vistas a compor um corpus de análise, Pym (1998, p. 66) destaca que, no seu estudo, "[...] [a] estratégia utilizada foi a de incluir somente aquelas instituições que ofertam um grau, um diploma ou um certificado que mencione as palavras 'tradução', 'tradutor, 'interpretação', intérprete' ou termos cognatos".

Sabemos que, segundo as atuais Diretrizes Curriculares Nacionais (DCN), os profissionais egressos dos cursos de Letras podem "[...] atuar como professores, pesquisadores, críticos literários, tradutores, intérpretes, revisores de textos, secretários, assessores culturais, entre outras atividades [...]" (Brasil, 2001, p. 30). Contudo, foram considerados aqui somente os bacharelados que tenham em seu título os termos Tradutor ou Tradução e que apresentem matrizes curriculares que reflitam tal formação,

10 Escolhemos apresentar aqui somente informações relacionadas diretamente a cursos que se apresentavam como destinados à formação de tradutoras e tradutores (profissionais) com vistas a uniformizar a análise, já que a formação de tradutólogas e tradutólogos visa à pesquisa (crítica) em Tradução, e não à prática tradutória. $11 \mathrm{O}$ par de língua Inglês/Português é o único comum a todos os bacharelados destinados à formação de tradutoras e tradutores no Brasil. e não a de professoras e professores de língua estrangeira. Tal escolha é justificada por acreditarmos, tal como Pym (1998), que devemos buscar construir um corpus de análise consistente com os objetivos de nossa pesquisa.

Deste modo, dos 11 bacharelados em Tradução ofertados nas IES públicas brasileiras, apresentaremos aqui somente oito ${ }^{12}$. Tal decisão se justifica pelos fatos de:

1) a Universidade Federal de Minas Gerais (UFMG) ter criado o bacharelado recentemente, isto é, ainda não tem turma formada e, consequentemente ainda não é reconhecido pelo Ministério da Educação;

2) a Universidade Federal do Paraná (UFPR) visar a formar pesquisadoras e pesquisadores em Tradução, tradutólogas e tradutólogos, tal como afirmado por Cardozo (2008; 2013) ${ }^{13}$;

3) a Universidade Estadual de Maringá (UEM) visar a formar, principalmente, professoras e professores de inglês, uma vez que, dos cinco anos do curso "Habilitação Única Inglês e Literaturas Correspondentes e Bacharelado em Tradução", somente o último é destinado ao Bacharelado em Tradução.

Em relação aos bacharelados privados, destacamos que a análise se deu inicialmente com base na matriz curricular das IES, já que não são disponibilizados os Projetos Pedagógicos

12 Bacharelados ofertados em IES públicas que visam à formação de tradutores e foram analisados: (1) Universidade Federal do Rio Grande do Sul (UfrGS); (2) Universidade Estadual Paulista "Júlio de Mesquita Filho" (Unesp); (3) Universidade de Brasília (UnB); (4) Universidade Federal de Juiz de Fora (UfJF); (5) Universidade Federal de Ouro Preto (UfOP); (6) Universidade Federal da Paraíba (UFPB); (7) Universidade Federal de Uberlândia (Ufu); (8) Universidade Federal de Pelotas (UfPel).

13 E como pudemos observar ao verificar a matriz curricular e o Projeto Pedagógico do Curso. 
de Curso (PPC) ou mesmo as ementas das disciplinas de alguns dos cursos. Assim, dos 18 bacharelados privados, pudemos analisar somente $10^{14}$, pois não tivemos acesso às demais matrizes curriculares ${ }^{15}$.

Sabemos que o currículo não pode ser compreendido somente como a matriz curricular dos cursos em questão, tal como afirmado por Goodson (2013). Porém, a análise de matrizes curriculares pode nos auxiliar, em um primeiro momento, a verificar se há realmente diferentes tradições relacionadas à formação de tradutoras e tradutores no Brasil.

Deste modo, apresentaremos aqui um recorte quanto à concepção curricular dos bacharelados em Tradução no Brasil no par de línguas Inglês/Português, comum a todas as IEs públicas e privadas. Porém, salientamos que outras opções de Língua B também são ofertadas nas IES públicas (Gráficos 3 e 4). Dos cursos ofertados em IEs privadas, somente a Universidade Paulista (Unip) oferece a formação de tradutoras e tradutores no par de línguas Espanhol/ Português.

14 Bacharelados que visam à formação de tradutores ofertados em IES privadas e foram analisados: (1) Pontifícia Universidade Católica do Rio de Janeiro (PUC-Rio); (2) Centro Universitário Anhanguera de São Paulo (Anhanguera); (3) Pontifícia Universidade Católica de São Paulo (PUC-SP); (4) Universidade Sagrado Coração (USC); (5) Universidade Católica de Santos (UniSantos); (6) Universidade São Judas Tadeu (USJT); (7) Centro Universitário Adventista de São Paulo (UNASP); (8) Universidade Metodista de São Paulo (UMESP); (9) Faculdade Integrada Brasil Amazônia (FIBRA); (10) Instituto Superior Anísio Teixeira (ISAT).

15 Bacharelados que visam à formação de tradutores ofertados em IES privadas e não foram analisados: (1) Faculdades Metropolitanas Unidas (FMU); (2) Universidade de Franca (UNIFran); (3) União das Faculdades dos Grandes Lagos (UnILAGO); (5) Universidade Metodista de Piracicaba (UnimeP); (6) Universidade Anhanguera UNIDERP; (7) Faculdade Cultura Inglesa.
Para que tal análise fosse possível, a matriz curricular de cada IEs foi classificada em 12 categorias a partir da carga horária de disciplinas obrigatórias: (1) Língua A; (2) Língua B; (3) Língua C; (4) Literatura Brasileira; (5) Literatura Estrangeira; (6) Teoria da literatura; (7) Linguística; (8) Estudos Culturais; (9) Estudos da Tradução (teoria); (10) Estudos da Tradução (prática de tradução); (11) Estudos da Tradução (prática de interpretação); (12) Outros. Assim, pudemos analisar a porcentagem de cada categoria em relação à carga horária total de disciplinas obrigatórias de cada bacharelado, uma vez que cada um deles apresenta diferentes cargas horárias totais.

\section{Aspectos relativos à formação de tradutoras e tradutores}

Conforme González Davies (2004), a formação de tradutoras e tradutores é ofertada principalmente em programas de graduação, exceto em países de língua inglesa, que oferecem tal formação principalmente na pós-graduação. No Brasil, a formação de tradutoras e tradutores é realizada em programas de graduação (bacharelados), enquanto que na pós-graduação (mestrado e doutorado) são formados pesquisadoras e pesquisadores em Tradução.

Conforme Venuti (2017), em razão da emergência global da formação de tradutoras e tradutores, um currículo razoavelmente padrão ao ensino de Tradução passou a vigorar em todo mundo e é caracterizado pela presença maciça de disciplinas obrigatórias destinadas às discussões teóricas e à prática da tradução. Porém, conforme Dorothy Kelly e Anne Martin (2009), os programas universitários destinados à formação de tradutoras e tradutores, em geral, apresentam uma oferta maior de disciplinas teóricas, ao passo que nos cursos profissionalizantes não universitários a propor- 
Opções de língua $B$ ofertadas por bacharelados destinados à

formação de tradutoras e tradutores em IES públicas

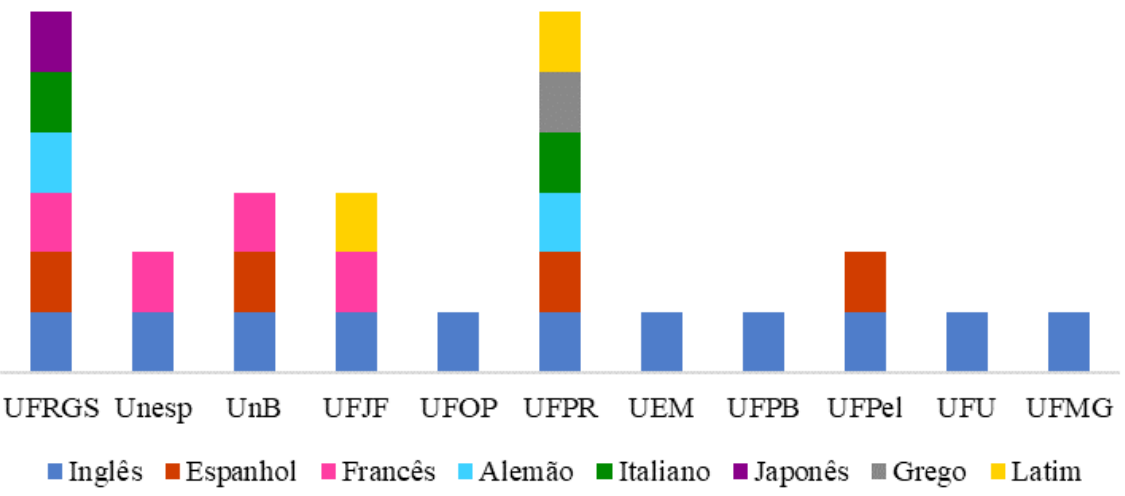

Gráfico 3. Opções de língua B ofertadas em bacharelados destinados à formação de tradutoras e tradutores em IEs públicas. Elaboração: Costa (2018).

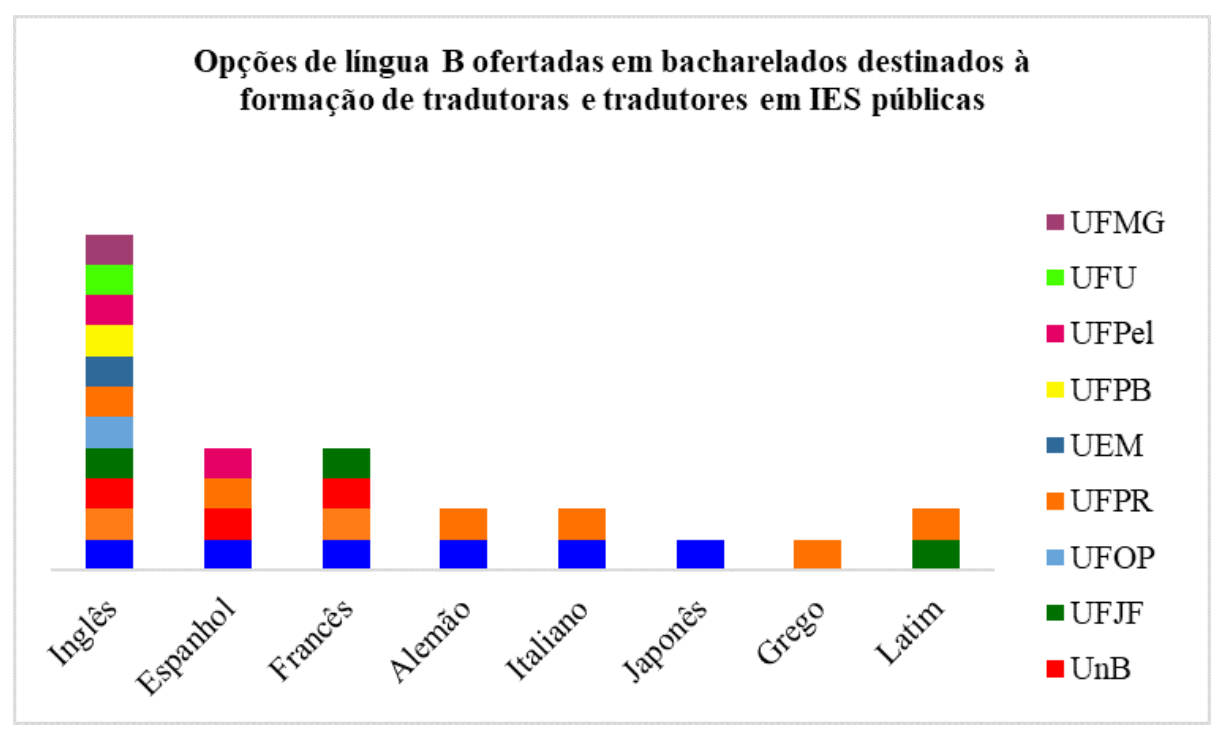

Gráfico 4. Opções de língua B ofertadas em bacharelados destinados à formação de tradutoras e tradutores em IEs públicas. Elaboração: gráfico fundamentado nos dados de Costa (2018).

ção entre teoria e prática é inversa, ofertam-se mais disciplinas práticas que teóricas. Destacam ainda que os programas de graduação em Tradução têm por tradição ofertar uma formação generalista. Ainda a respeito da dicotomia teoria-prática, Bartrina (2005) enfatiza que a oferta de disciplinas teóricas é primordial para a formação de tradutoras e tradutores e elas não devem ser entendidas como um fim em si mesmas, razão pela qual questões teóricas devem ser reapresentadas nas disciplinas dedicadas à prática tradutória.

Salientamos ainda que, conforme Valentine (1996), tradutoras e tradutores devem conhecer bem a língua estrangeira para a qual tradu- 
zem (Língua B) e dominar sua língua materna (Língua A). De modo a complementar tal afirmação, Shäffner e Adab (2000) e Gonçalves e Machado (2006) ressaltam que muitos dos cursos voltados à formação de tradutores não ofertam disciplinas voltadas ao estudo da língua materna (Língua A). Esses afirmam ainda que a formação de tradutoras e tradutores não deve ser resumida à aquisição de habilidades voltadas à prática, mas deve ter também fundamentação teórica. Nord (2005a, 2005b) salienta ainda a relevância de se ofertarem disciplinas destinadas a uma segunda língua estrangeira (Língua C).

No que diz respeito ao contexto brasileiro, segundo o Ministério da Educação, é facultado às Instituições de Ensino Superior (IES) a concepção curricular de cursos que não possuem Diretrizes Curriculares Nacionais (DCN) próprias (Brasil, 2015), como é o caso das graduações destinadas à formação de tradutoras e tradutores e mesmo de intérpretes. Como se pode verificar, a maioria dos Bacharelados em Tradução estão inseridos em um contexto relacionado ao curso de Letras, o que pode justificar o uso das Diretrizes Curriculares Nacionais (DCN) para o curso de Letras como base para a construção da matriz curriculares destes cursos. Deste modo, os bacharelados voltados à formação de tradutoras e tradutores, muitas vezes, são extremamente influenciados pela DCN para o curso de Letras, como pode ser constatado a seguir:

Considerando os diversos profissionais que o curso de Letras pode formar, os conteúdos caracterizadores básicos devem estar ligados à área dos Estudos Lingüisticos e Literários, contemplando o desenvolvimento de competências e habilidades específicas. Os estudos linguísticos e literários devem fundar-se na percepção da língua e da literatura como prática social e como forma mais elaborada das manifestações culturais. Devem articular a reflexão teórico-crítica com os domínios da prática - essenciais aos profissionais de Letras, de modo a dar prioridade à abordagem intercultural, que concebe a diferença como valor antropológico e como forma de desenvolver o espírito crítico frente à realidade. (Brasil, 2001a, p. 31. Grifos nossos).

Contudo, esse estabelecimento de conteúdos caracterizadores básicos contradiz, em parte, o Parecer CNE $n^{\circ}$ 776/97 (Brasil, 1997), segundo o qual cada DCN deve evitar ao máximo a fixação de conteúdos, não podendo exceder $50 \%$ da carga horária total dos cursos (Brasil, 1997) e evitando, assim, a rigidez que os currículos mínimos impunham até 1996. Deste modo, o currículo passa a ser constituído pelos objetivos, pelos conhecimentos, pelas competências e pelas habilidades necessárias a determinada formação (Brasil, 2001a).

Tal como Paschoal (2007), Pym (2009) e Gonçalves (2015), acreditamos que a formação de tradutoras e tradutores difere da formação de professoras e professores de línguas estrangeiras; assim, é preciso que tal entendimento se reflita também na concepção curricular. Desse modo, os conhecimentos advindos do curso de Letras podem ser abordados de diferentes maneiras no decorrer da formação de tradutoras e tradutores, mas deve-se observar que os Bacharelados em Tradução não devem ser pensados ou compreendidos como cursos de Letras.

Ressaltamos ainda que, conforme estabelecido no Parecer CNE/CES n ${ }^{\circ}$ 8/2007 (Brasil, 2007), foram instituídas cargas horárias mínimas para a integralização de cursos de graduação. A carga horária varia de bacharelado a bacharelado e a carga horária mínima para os cursos de Letras é de 2.400 horas, com duração entre três e quatro anos (Quadro 1), podendo se estender conforme a ampliação da carga horária. Destacamos ainda que cada IES pode propor a carga horária desejada para a 
integralização de cada curso, devendo, porém, evitar o prolongamento do curso.

Quadro 1. Carga horária e duração mínima para integralização do curso de graduação, bacharelado, modalidade presencial

\begin{tabular}{lc}
\hline $\begin{array}{l}\text { Carga horária } \\
\text { mínima (horas) }\end{array}$ & $\begin{array}{c}\text { Duração para integralização } \\
\text { do curso (anos) }\end{array}$ \\
\hline 2.400 & 3 ou 4 \\
2.700 & 3,5 ou 4 \\
Entre 3.000 e 3.200 & 4 \\
Entre 3.600 e 4.000 & 5 \\
7.200 & 6 \\
\hline
\end{tabular}

Elaboração: Costa (2018, p 370)

\subsection{As Instituições de Ensino Superior públicas}

Todos os bacharelados ofertados em Instituições de Ensino Superior (IES) públicas brasileiras, como informado anteriormente, apresentam em seu título os termos Tradutor ou Tradução. Além disso, dos 11 bacharelados destinados à formação de tradutoras e tradutores ofertados atualmente por IES públicas brasileiras, somente três não estão vinculados ao curso de Letras (Quadro 2).

Ademais, cada um dos oito bacharelados analisados (UFRGs, Unesp, UnB, UFOP, UFJF, UFPB, UFU, UFPel), ofertados em IES públicas, apresentam diferentes cargas horárias totais ${ }^{16} \mathrm{e} \mathrm{du}$ ram de três anos e meio a quatro anos. Além

16 1) UFRGS - 2.700 horas/aula, todas de disciplinas obrigatórias; (2) Unesp - 3.150 horas/aula, todas de disciplinas obrigatórias; (3) UnB -2.700 horas/aula, das quais 2.460 horas/aulas de disciplinas obrigatórias; (4) UFJF - 2.475 horas/aula, sendo 2.235 horas/aulas de disciplinas obrigatórias; (5) UFOP - 2.610 horas/aula, sendo 2.040 horas/aulas de disciplinas obrigatórias; (6) UFPB -2.445 horas/aula, sendo 1.845 horas/aula de disciplinas obrigatórias; (7) UFU -2.480 horas/aula, sendo disso, diversas são as especificidades de cada bacharelado, como veremos adiante.

No que diz respeito à oferta de disciplinas relacionadas à língua materna (Língua $\mathrm{A}$ ) e à(s) língua(s) estrangeira(s) (Línguas B e C) (Gráfico 5), podemos afirmar que as concepções curriculares dos bacharelados ofertados por IES públicas brasileiras vão ao encontro das afirmações de Shäffner e Adab (2000) e Gonçalves e Machado (2006): poucos são os cursos que ofertam disciplinas voltadas ao estudo da língua materna (A), possivelmente por pressuporem que tradutoras e tradutores em formação adquiriram tal conhecimento durante seus anos escolares.

Disciplinas obrigatórias de língua portuguesa (Língua A) são ofertadas na maioria dos oito bacharelados analisados, exceto na UFPB. Porém, esta oferta pode ser classificada como reduzida ou mesmo insuficiente, visto que somente de $2,68 \%$ (UFJF) a $6,67 \%$ (UFRGS) da carga horária total de disciplinas obrigatórias dos cursos refere-se ao ensino de português.

Deste modo, a primeira língua estrangeira (Língua B) ocupa local de destaque na carga horária total dos cursos. Como se pode perceber, entre $16,4 \%$ (UnB) e $27,25 \%$ (UFpel) da carga horária total de disciplinas obrigatórias refere-se ao ensino de inglês nos bacharelados voltados à formação de tradutoras e tradutores. Assim, poderíamos nos questionar, entre outras possibilidades, se o ensino de inglês é específico para a formação de tradutoras e tradutores ou se as tradutoras e os tradutores em formação compartilham das mesmas disciplinas destinadas à formação de professores de línguas estrangeiras, tal como questionado por Briks (no prelo).

2.100 horas/aula de disciplinas obrigatórias; (8) UFPel 2.805 horas/aula, todas disciplinas obrigatórias. 
Quadro 2 - Denominação dos bacharelados destinados à formação de tradutores nas Instituições de Ensino Superior (IES) públicas brasileiras*

\begin{tabular}{|c|c|}
\hline IES Pública & Denominação do bacharelado \\
\hline UFRGS & Bacharelado em Letras - Habilitação Tradutor \\
\hline Unesp & Bacharelado em Letras com Habilitação de Tradutor \\
\hline UnB & Bacharelado em Letras - Tradução \\
\hline UFOP & Letras - Bacharelado em Tradução \\
\hline UFJF & Bacharelado em Letras - Tradução \\
\hline UFPR & Letras - Ênfase em Estudos da Tradução \\
\hline UEM & $\begin{array}{l}\text { Letras - Habilitação Única: Inglês e Literaturas correspondentes Licenciatura e Bacharelado em } \\
\text { Tradução }\end{array}$ \\
\hline UFPB & Bacharelado em Tradução \\
\hline UFU & Bacharelado em Tradução \\
\hline UFPel & Bacharelado em Letras Tradução \\
\hline UFMG & Bacharelado em Tradução \\
\hline
\end{tabular}

* Bacharelados não analisados em razão dos critérios adotados: UFPR, UEM e UFMG.

Fonte: Costa (2018, p. 230. Adaptado)

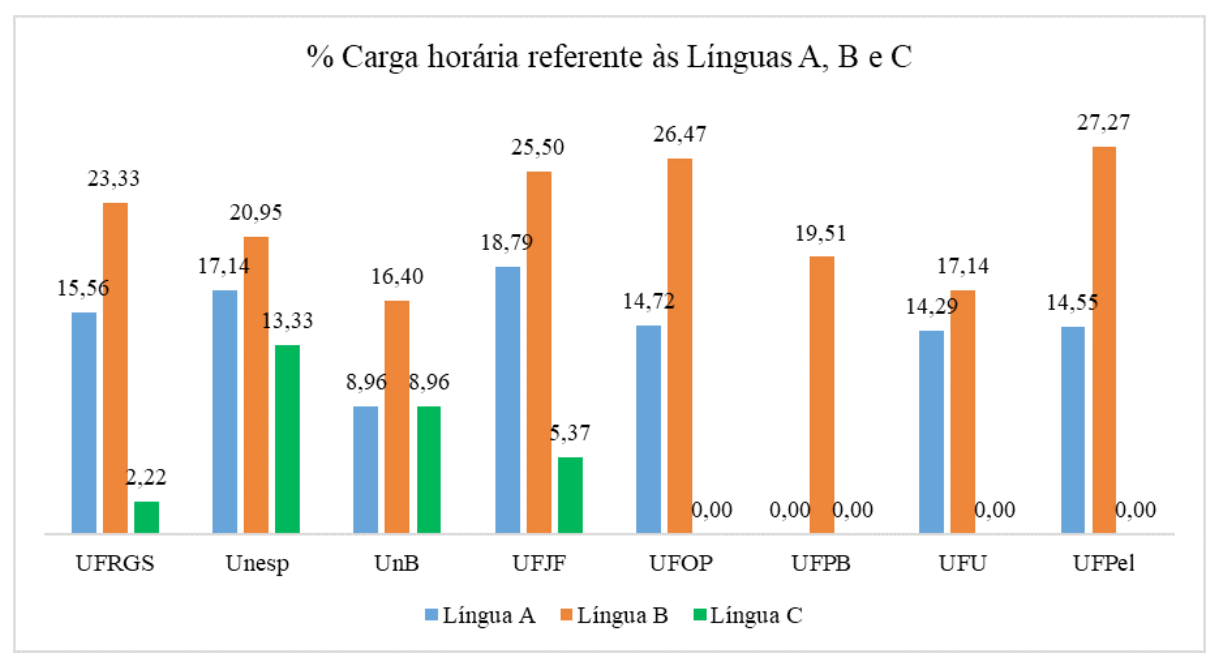

Gráfico 5. Porcentagem da carga horária referente às Línguas A, B e C em relação à carga horária total em bacharelados destinados à formação de tradutores em IEs públicas. Elaboração: gráfico fundamentado nos dados de Costa (2018). 
Já no que diz respeito à oferta obrigatória de uma segunda língua estrangeira (Língua C), somente quatro IES ofertam disciplinas obrigatórias que permitam seu estudo (UFRGS, Unesp, UnB e UfJF), sendo essa uma grande diferença do contexto brasileiro para o europeu (Nord, 2005a, 2005b).

Outra particularidade analisada refere-se à porcentagem de carga horária destinada aos estudos literários em relação à carga horária total. Verificamos que as concepções curriculares da maioria dos bacharelados vão ao encontro da proposta das Diretrizes Curriculares Nacionais para o curso de Letras, isto é, a oferta de conteúdos caracterizadores básicos ligados à área dos Estudos Literários (Brasil, 2001a).

Como pode ser constatado pelo Gráfico 6, a oferta de disciplinas obrigatórias destinadas à discussão de literatura estrangeira é presente na maioria dos cursos, exceto aqueles da UFPB e da UFPel, e tem um porcentual da carga horária total de disciplinas obrigatórias que varia entre $2,86 \%$ (UFU) e $14,42 \%$ (UFJF). Por outro lado, as disciplinas de literatura brasileira são ofertadas em somente quatro dos oito bacharelados, e apresentam uma porcentagem da carga horária total de disciplinas obrigatórias diminuta, variando de $2,68 \%$ (UFJF) a $6,67 \%$ (UFRGS), assim como aquela da língua $\mathrm{A}$. Por outro lado, com exceção da UnB, os demais bacharelados ofertam disciplinas obrigatórias relacionadas à Teoria da Literatura, com uma porcentagem da carga horária total de disciplinas obrigatórias variando entre $2,22 \%$ (UFRGS) e $8,82 \%$ (UFOP).

Com relação às disciplinas obrigatórias que podem ser classificadas como teóricas (Gráfico 7), constatamos, mais uma vez, que as concepções curriculares são coerentes com a proposta das DCN para o curso de Letras, haja vista que disciplinas obrigatórias da área de Estudos Linguísticos e Literários são ofertadas em praticamente todos os bacharelados em questão. Além disso, são ofertadas disciplinas relacionadas aos Estudos Culturais na UFRGS (3,92\%), UnB (4,44\%) e Unesp $(8,57 \%)$, tal como proposto por Valentine (1996), Schäffner e Adab (2000) e Venuti (2017).

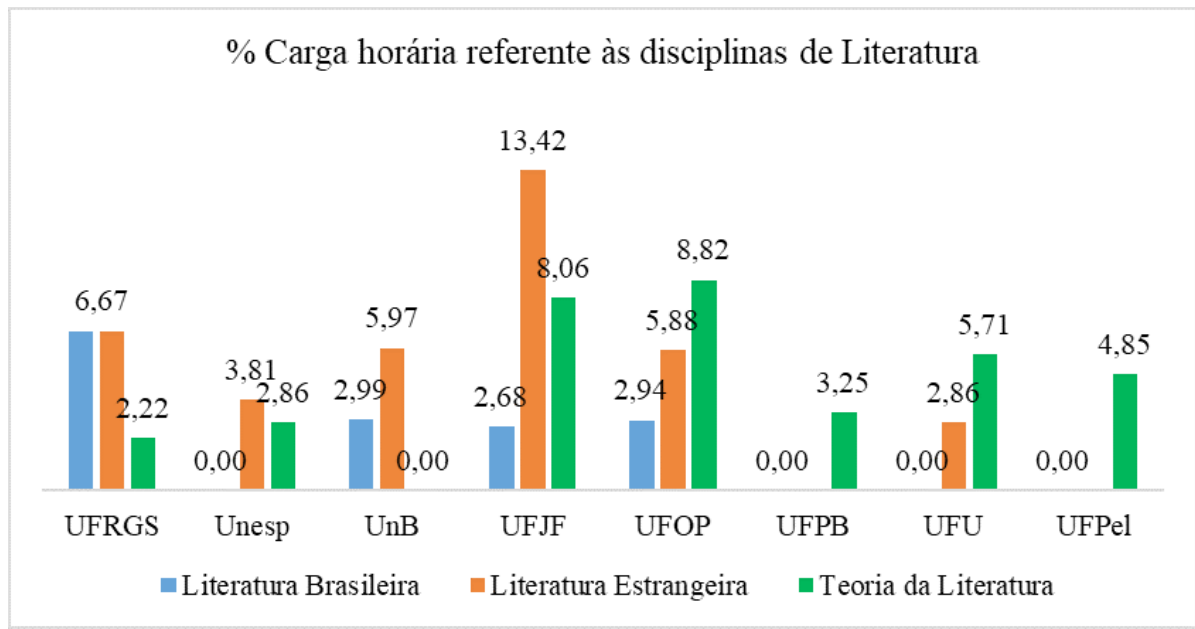

Gráfico 6. Porcentagem da carga horária referente às disciplinas de Literatura em relação à carga horária total em bacharelados destinados à formação de tradutores em IEs públicas. Elaboração: gráfico fundamentado nos dados de Costa (2018) 


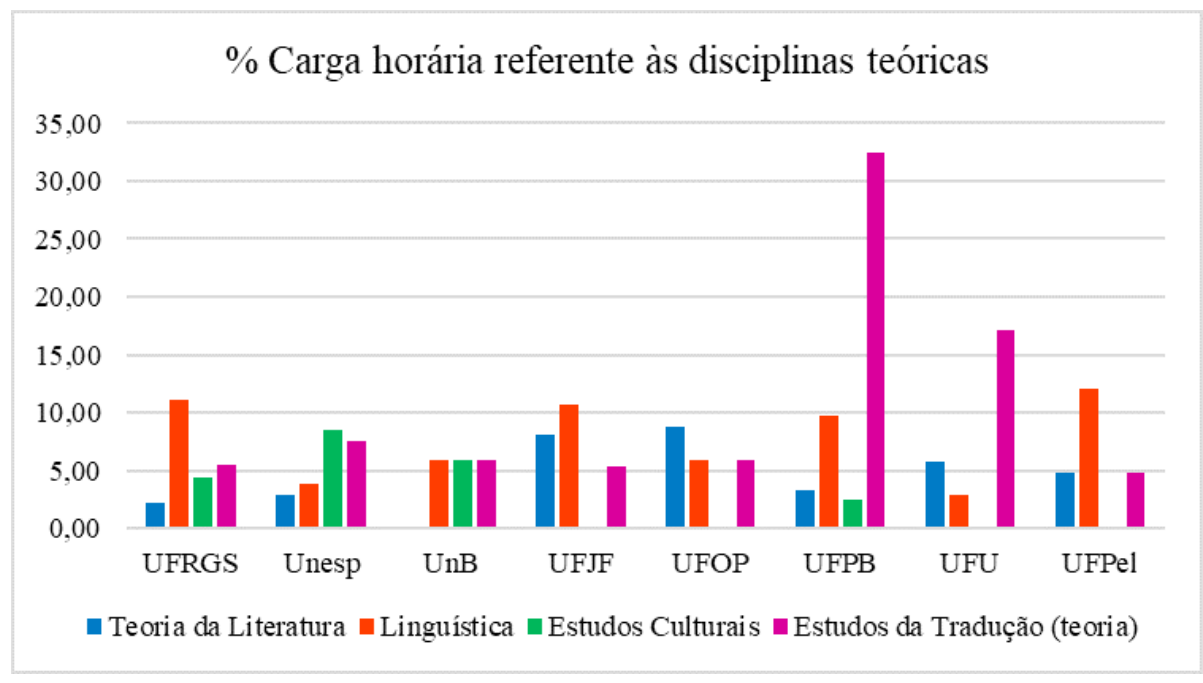

Gráfico 7. Porcentagem de carga horária referente às disciplinas teóricas em relação à carga horária total em bacharelados destinados à formação de tradutores em IEs públicas. Elaboração: gráfico fundamentado nos dados de Costa (2018).

No que diz respeito à área dos Estudos da Tradução, considerada como conteúdo profissionalizante, são ofertadas disciplinas obrigatórias teóricas em todos os bacharelados, porém com uma variação de $4,85 \%$ (ufpel) a $32,52 \%$ (ufpb) da carga horária total de disciplinas obrigatórias. Conforma-se mais uma vez à proposta das dcn para o curso de Letras, o qual deve ser consolidado a partir de uma abordagem intercultural em que a percepção de língua e literatura deveria se fundamentar na prática social e nas manifestações culturais (Brasil, 2001a).

Salientamos que a carga horária destinada aos conteúdos da área dos Estudos da Tradução, seja por meio de disciplinas teóricas, seja por práticas, e que representa diretamente os conteúdos caracterizadores da formação profissional em tradução, ainda poderia ser considerada aquém do esperado. Como pode ser verificado no Gráfico 8 , não há, ainda, um acordo no que diz respeito à porcentagem de carga horária destinada às disciplinas obrigatórias profissionalizantes da área da tradução. Enquanto a Unesp oferta 7,62\% e 19,05\% de sua carga horária total, respectivamente, para as disciplinas teóricas da área dos Estudos da Tradução e práticas de Tradução, a UFPB oferta $32,52 \%$ e $29,27 \%$, respectivamente.

Além disso, uma vez que os bacharelados não apresentam em seu título o termo "intérprete" ou "interpretação", a ausência de disciplinas para essa especialidade nos bacharelados é justificada. Destacamos, porém, que entre os bacharelados analisados, o programa da UFU foi o único a apresentar uma disciplina voltada à interpretação.

Por fim, alguns bacharelados ainda ofertam disciplinas que não podem ser inseridas em nenhuma das categorias estipuladas para esta análise e que variam entre $0 \%$ e $7,27 \%$ da carga horária total de disciplinas obrigatórias. Estas disciplinas fazem parte, por vezes, do quadro de disciplinas caracterizador das licenciaturas, cursos destinados à formação de professores, como, por exemplo, Fundamentos da Educação, da área das Ciências da Educação. 


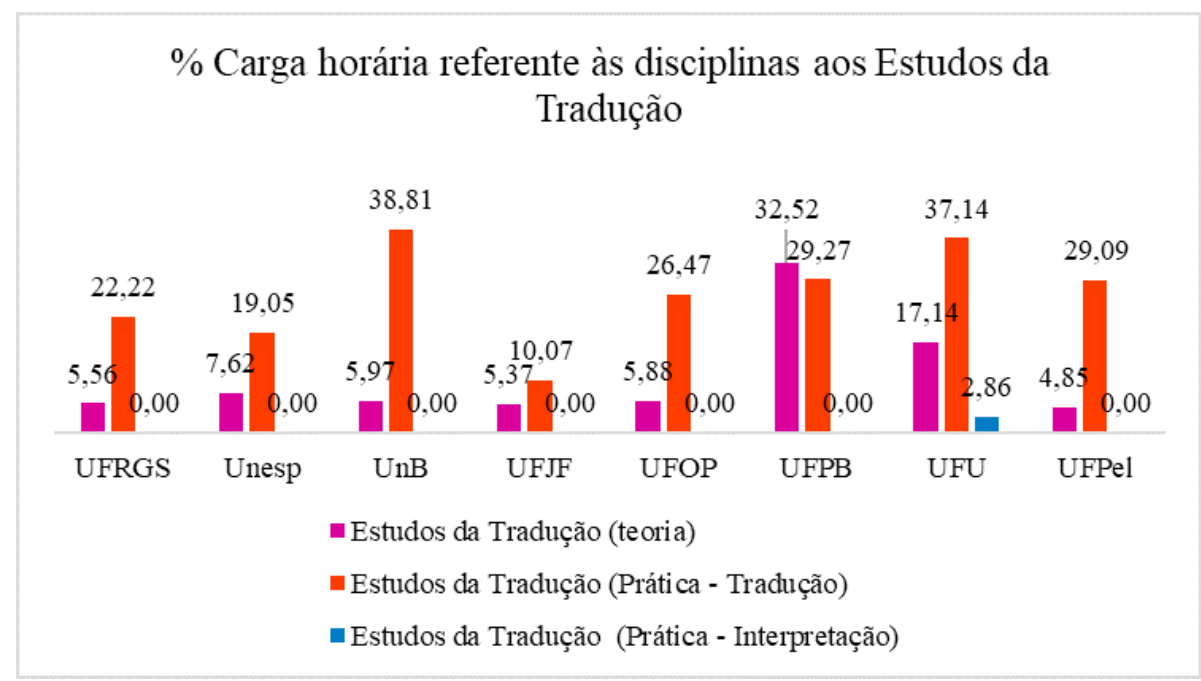

Gráfico 8. Porcentagem de carga horária referente às disciplinas dos Estudos da Tradução em relação à carga horária total em bacharelados destinados à formação de tradutores em IEs públicas. Elaboração: gráfico fundamentado nos dados de Costa (2018).

\subsection{As Instituições de Ensino Superior privadas}

Todos os bacharelados ofertados em Instituições de Ensino Superior (IES) privadas brasileiras, como informado anteriormente, apresentam em seu título o termo Tradutor ou Tradução. Ademais, dos 18 bacharelados destinados à formação de tradutores ofertados atualmente por IES privadas brasileiras, 11 também levam em seu título o termo Intérprete ou Interpretação. Além disso, dos 18 bacharelados destinados à formação de tradutores ofertados atualmente por IES privadas brasileiras, somente três não são vinculados ao curso de Letras (Quadro 3).

Assim como para as IES públicas, chamamos atenção para o fato de que cada um dos bacharelados analisados, ofertados em IES privadas, apresentam diferentes cargas horárias totais ${ }^{17}$ e duram de três a quatro anos.

17 1) PUC-Rio: 2.700 horas/aula, sendo 1.980 horas/aulas de disciplinas obrigatórias; 2) Anhanguera: 3.000 horas/ aula, sendo 2.820 horas/aulas de disciplinas obrigatórias; 3) PUC - SP: 2.592 horas/aula, sendo todas as disciplinas
No que diz respeito às disciplinas relacionadas à língua materna e à(s) língua(s) estrangeira(s) (Gráfico 9), chama atenção o fato que dos 10 bacharelados ofertados em IES, todas as concepções curriculares apresentam disciplinas obrigatórias de língua portuguesa, variando entre $2,99 \%$ (Umesp) e 19,29\% (ISAT) da carga horária total de disciplinas obrigatórias. No que diz respeito à oferta de disciplinas obrigatórias destinadas ao estudo da primeira língua estrangeira (Língua B), a carga horária total de disciplinas obrigatórias varia entre 7,7\% (UniSantos) e $26,39 \%$ (PUC-SP). Já no tocante à segunda língua estrangeira (Língua $\mathrm{C}$ ), somente

obrigatórias; 4) USC: 2.728 horas/aula, sendo 2.524 horas/aulas de disciplinas obrigatórias; 5) UniSantos: 2.890 horas/aula, sendo 2.650 horas/aulas de disciplinas obrigatórias; 6) UsjT: 3.200 horas/aula, sendo todas obrigatórias; 7) Unasp: 2.890 horas/aula, sendo 2.746 horas/ aulas de disciplinas obrigatórias; 8) Umesp: 2.880 horas/ aula, sendo 2.680 horas/aulas de disciplinas obrigatórias; 9) FIBRA: 3.640 horas/aula, sendo 3.360 horas/aulas de disciplinas obrigatórias; 10) ISAT: 2.956 horas/aula, sendo 2.812 horas/aulas de disciplinas obrigatórias. 
Quadro 3. Denominação dos bacharelados destinados à formação de tradutores nas Instituições de Ensino Superior (IES) privadas brasileiras*

\begin{tabular}{|c|c|}
\hline IES Privada & Denominação do bacharelado \\
\hline PUC-Rio & Letras - Tradução (Bacharelado em Português - Inglês-Tradutor) \\
\hline FIA (Anhanguera) & Letras - Habilitação em Tradutor Intérprete \\
\hline PUC-SP & Bacharelado em Letras - Tradução Inglês e Português \\
\hline USC & Bacharelado em Letras - Tradutor \\
\hline UNIP & Letras - Bacharelado em Tradução \\
\hline UniSantos & Bacharelado em Tradução e Interpretação \\
\hline USJT & Bacharelado em Letras - Tradutor e Intérprete \\
\hline UNIDERP & Letras - Bacharelado com ênfase em Tradutor e Intérprete em Língua Inglesa \\
\hline Unifran & Letras Tradutor e Intérprete \\
\hline Unasp & Bacharelado em Tradutor e Intérprete \\
\hline UNILAGO & Letras - Tradutor Intérprete (Língua Inglesa) \\
\hline FMU & Letras (Tradução - Inglês/Português) \\
\hline UNINOVE & Bacharelado em Tradutor e Intérprete \\
\hline UMESP & Letras - Tradutor e Intérprete em Inglês \\
\hline FIBRA & Letras Bacharelado (Titulação: Bacharel em Tradução e Interpretação em Português/Inglês) \\
\hline ISAT & Bacharelado em Letras - Tradução Português e Inglês \\
\hline UNIMEP & Bacharelado em Letras - Inglês - Tradução e Interpretação \\
\hline $\begin{array}{l}\text { Faculdade } \\
\text { Cultura Inglesa }\end{array}$ & Bacharelado em Letras - Inglês - Tradução \\
\hline
\end{tabular}

* Bacharelados não analisados em razão dos critérios adotados: Unip, uniderp, Unifran, Unilago, FMU, Unimep e Faculdade Cultura Inglesa. Na Unip, segundo o edital para ingresso no bacharelado destinado à formação de tradutores, o ingressante deverá ter formação prévia no curso de Letras (Costa, 2018).

Fonte: Costa (2018, p. 231. Adaptado)

quatro dos 10 bacharelados ofertam disciplinas obrigatórias destinadas a este estudo.

Assim como as concepções curriculares dos bacharelados ofertados pelas IES públicas, os bacharelados das IES privadas vão ao encontro das DCN para o curso de Letras, visto que o componente relacionado aos Estudos Literários está presente em todos os cursos analisados (Gráfico 10). Porém, tal como nas IES públicas, a oferta de disciplinas obrigatórias destinadas ao estudo da Literatura Brasileira é reduzida, estando presente em so- mente quatro dos 10 cursos, as quais variam entre $2,76 \%$ (ISAT) e $6,25 \%$ (USJT) da carga horária total de disciplinas obrigatórias. Por outro lado, oito dos 10 cursos ofertam disciplinas obrigatórias de literatura estrangeira, representando entre 4,26\% (Anhanguera) e $21,21 \%$ (PUC - Rio) da carga horária total de disciplinas obrigatórias. Por fim, todos os cursos ofertam disciplinas obrigatórias relacionadas à Teoria da Literatura, com uma variação entre 2,13\% (Anhanguera) e 10,45\% (Umesp) da carga horária total de disciplinas obrigatórias. 


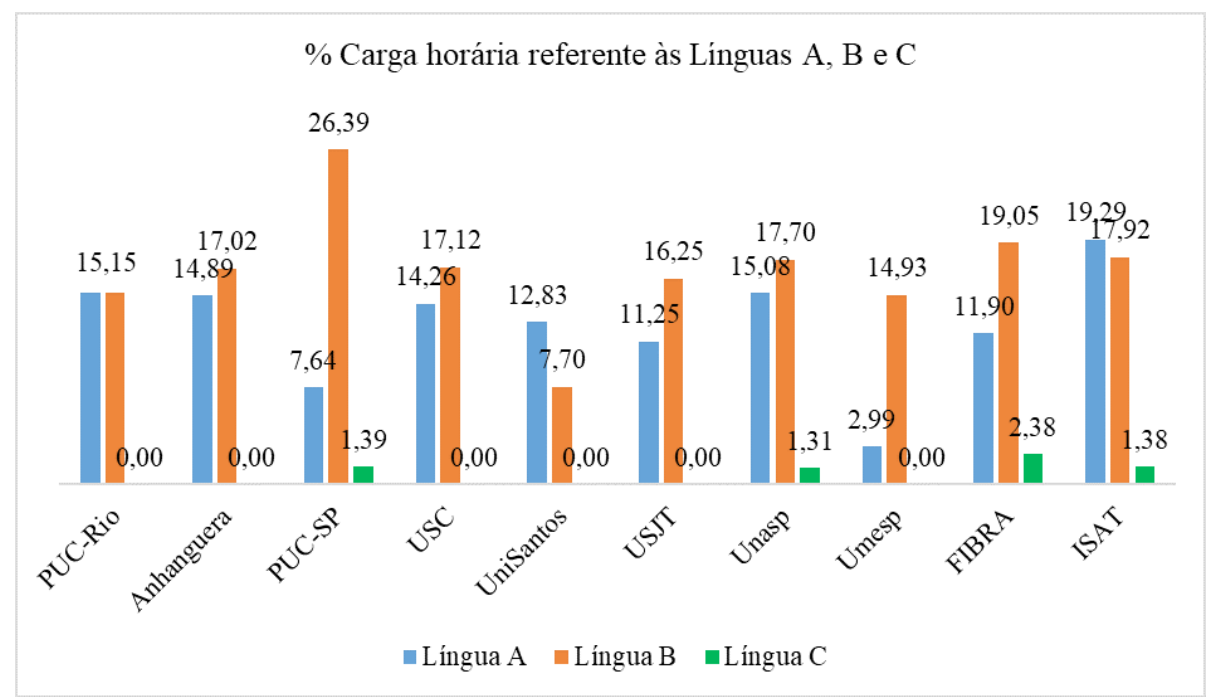

Gráfico 9. Porcentagem de carga horária referente às Línguas A, B e C em relação à carga horária total em bacharelados destinados à formação de tradutores em IEs privadas. Elaboração: gráfico fundamentado nos dados de Costa (2018)

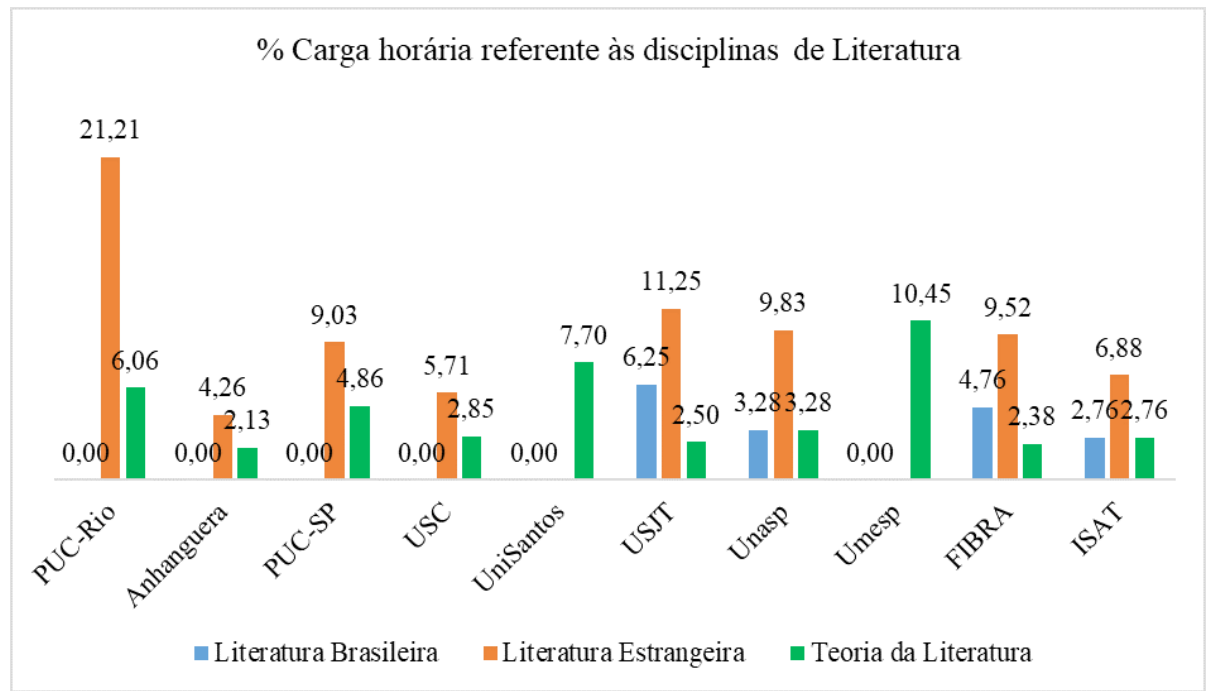

Gráfico 10. Porcentagem da carga horária referente às disciplinas de Literatura em relação à carga horária total em bacharelados destinados à formação de tradutores em IEs privadas. Elaboração: gráfico fundamentado nos dados de Costa (2018)

Com relação às disciplinas obrigatórias que podem ser classificadas como teóricas (Gráfico 11), podemos constatar que, tal como nas IES públicas, os bacharelados ofertados nas IES privadas seguem as DCN para o curso de Letras, haja vista a porcentagem da carga horária destinada às disciplinas obrigatórias aos Estu- dos Literários, como visto anteriormente, e aos Estudos Linguísticos. Além disso, poucas são aquelas que ofertam disciplinas obrigatórias destinadas aos Estudos Culturais. Por fim, chama atenção o fato da pouca carga horária destinada às disciplinas obrigatórias para a área dos Estudos da Tradução, com variação 


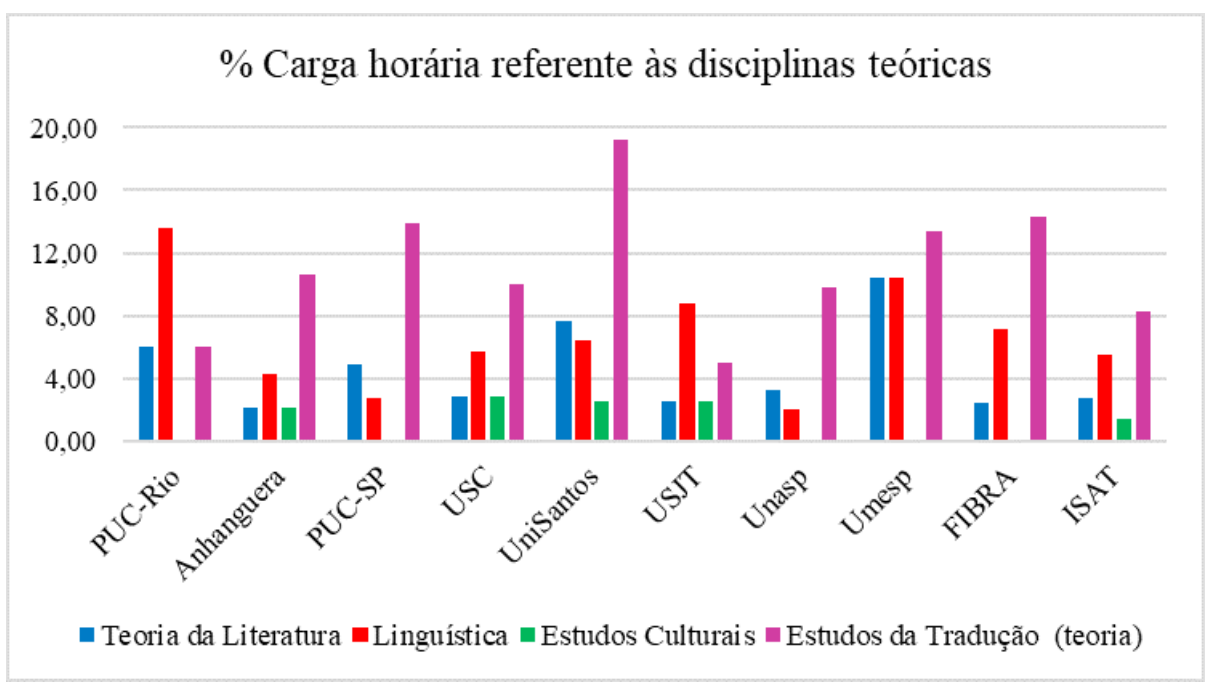

Gráfico 11. Porcentagem de carga horária referente às disciplinas teóricas em relação à carga horária total em bacharelados destinados à formação de tradutores em IEs privadas. Elaboração: gráfico fundamentado nos dados de Costa (2018)

entre 5,00\% (USJT) e 19,25\% (UniSantos) da carga horária total de disciplinas obrigatórias.

No que concerne à carga horária destinada aos Estudos da Tradução, o conteúdo profissionalizante, chama atenção o fato de que a carga horária voltada para as disciplinas teóricas é reduzida em todos os cursos. Já no tocante às disciplinas obrigatórias destinadas à prática tradutória, destacamos o fato de que alguns cursos ofertam tanto disciplinas de prática de tradução quanto de prática de interpretação (Gráfico 12).

Assim, a oferta de disciplinas de prática de tradução apresenta uma variação entre 7,50\% (USJT) e 30, 71\% (UniSantos) da carga horária total de disciplinas obrigatórias.

Chama atenção o fato de que, nos bacharelados que apresentam em seu título o termo "intérprete" ou "interpretação", a carga horária destinada à prática de interpretação é reduzida, variando entre 7,50 \% (USJT) e 11,94\% (Umesp). No entanto, chama mais atenção ainda o fato de que a graduação da Facul- dade Integrada Brasil Amazônia (FIBRA) não apresenta quaisquer disciplinas obrigatórias destinadas à interpretação, mesmo sendo o título do curso "Letras Bacharelado (Titulação: Bacharel em Tradução e Interpretação em Português/Inglês)".

Por fim, ressaltamos que, em alguns bacharelados, algumas disciplinas obrigatórias não puderam ser inseridas em nenhuma das 12 categorias estabelecidas para a análise do corpus. Entre elas, além de haver disciplinas características dos cursos de Letras destinados à formação de professores, algumas instituições de cunho confessional também ofertam disciplinas relacionadas à discussão de aspectos religiosos. Deste modo, entre 2,38\% (FIBRA) e $21,28 \%$ (Anhanguera) da carga horária total de disciplinas obrigatórias são destinadas a disciplinas que não puderam ser inseridas em nenhuma das 12 categorias.

\section{Considerações Finais}

Esse artigo teve por objetivo apresentar uma discussão relativa à concepção curricular de 


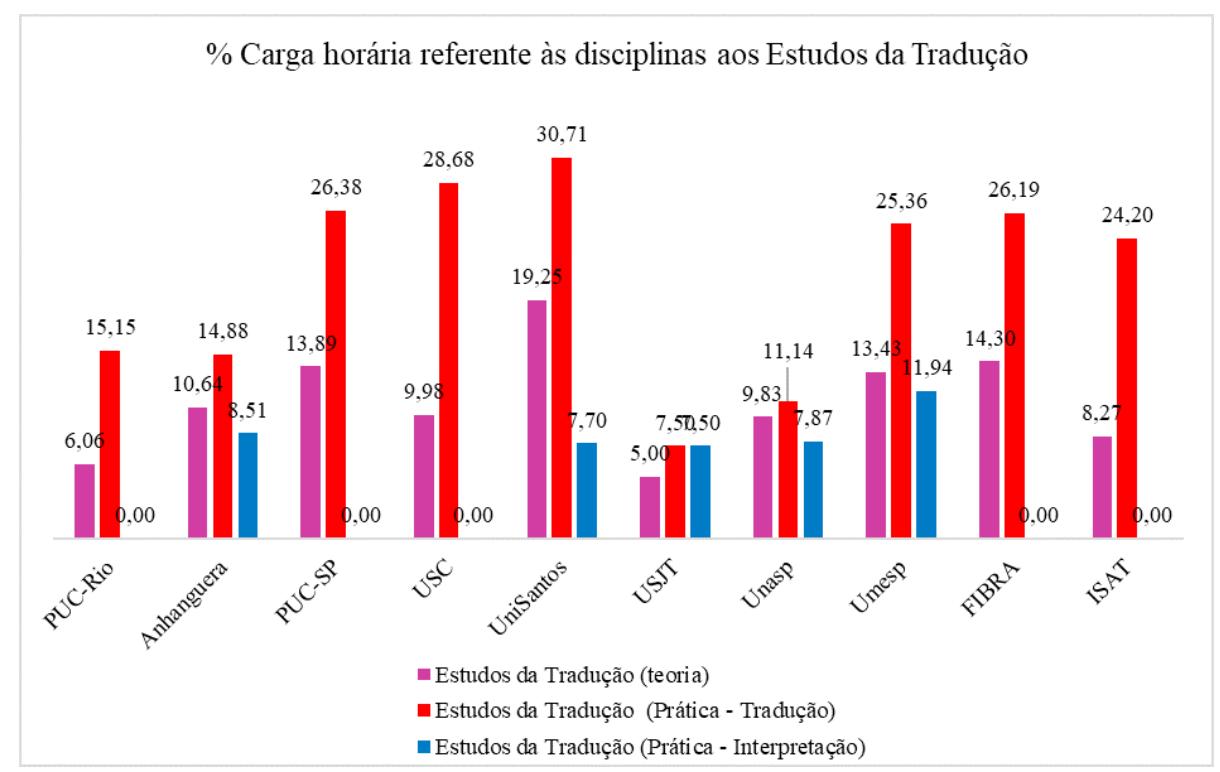

Gráfico 12. Porcentagem de carga horária referente às disciplinas aos Estudos da Tradução em relação à carga horária total em bacharelados destinados à formação de tradutores em IEs privadas. Elaboração: gráfico fundamentado nos dados de Costa (2018)

programas de graduação que têm por finalidade a formação de tradutoras e tradutores de línguas orais no par Português/Inglês nas Instituições de Ensino Superior (IES) públicas e privadas brasileiras, fundamentando-se na análise documental (Scott, 2006; Cohen; Manion; Morrison, 2007), respaldada pela abordagem qualiquantitativa (Lamoureux, 2003; Cohen; Manion; Morrison, 2007; Thouin, 2014). Apresentamos, assim, o contexto histórico da formação de tradutores em nível universitário, tanto em IES públicas quanto em IES privadas. Em seguida, expusemos a concepção curricular dos bacharelados que cumpriam os critérios estabelecidos para a construção de nosso corpus.

Os bacharelados em Letras-Tradução ou Tradução apresentam diferentes cargas horárias totais, sendo as mínimas e máximas nas IES públicas, respectivamente, 2.445 horas na UFPB e 3.150 na Unesp, e nas IES privadas, 2.592 horas na PUC-SP e 3.640 horas na FIBRA. É a carga horária total que estabelece diretamente a duração para a integralização do curso (cf. Quadro 1). Assim, podemos ter bacharelados com duração de três anos ou mesmo de cinco anos, como é o caso da FIBRA.

Lembramos que a elaboração de matrizes curriculares está diretamente relacionada às relações sociais e de poder, tal como afirma Goodson (2013). As graduações em Letras fundamentam-se nas Diretrizes Nacionais Curriculares para os cursos de Letras (Brasil, 2001, p. 30), segundo as quais tais cursos formariam também tradutores e tradutoras. Assim, o surgimento de graduações em Letras/Tradução ou somente Tradução podem ser consideradas resultado de necessidades sociais.

Como pode ser percebido pela linha do tempo da criação dos bacharelados em Tradução no Brasil (cf. Gráfico 1 e 2), enquanto a criação de bacharelados em Letras-Tradução e/ ou Tradução em IES públicas se deu principalmente durante a Ditadura Militar brasileira e durante o Governo Lula, em razão do REUNI, 
aqueles das IES privadas foram criados principalmente durante o governo FHC, conhecido pelo aumento das privatizações e sucateamento das IEs públicas.

Como foi possível perceber no decorrer do texto, os bacharelados ofertados pelas IES brasileiras diferem entre si pela carga horária total, pelos pares linguísticos ofertados, pela carga horária das disciplinas obrigatórias e, consequentemente, pela carga horária das diferentes categorias estabelecidas com vistas ao estudo apresentado. São esses aspectos que podem nos auxiliar a responder à seguinte questão: Há diferentes tradições no que diz respeito à formação de tradutoras e tradutores no Brasil?

Inicialmente, podemos afirmar que sim. E podemos justificar tal afirmação com a simples constatação: enquanto todas as IES privadas visam a formar tradutores e, por vezes, intérpretes, no par linguístico Inglês/Português, as IES públicas ofertam bacharelados em oito pares linguísticos diferentes. Das 11 IEs que ofertam bacharelados em Letras-Tradução ou Tradução, 11 ofertam o par linguístico Inglês/Português; quatro ofertam Espanhol/Português; quatro ofertam Francês/Português; duas, Alemão/Português; duas, Italiano/Português; duas, Latim/Português; uma, Japonês/Português; e uma, Grego/Português.

Enquanto os bacharelados em IEs públicas buscam formar somente tradutores, 11 das 18 das IES privadas afirmam formar tradutores e intérpretes. Entre as IES públicas, somente a UFU oferta uma disciplina obrigatória destinada à interpretação, Fundamentos da Interpretação, de 60 horas, que caracteriza 2,86\% da carga horária obrigatória. Já no que diz respeito às IEs privadas, essa porcentagem varia entre $7,7 \%$ e $11,94 \%$ da carga horária total, o que ainda é muito pouco para constituir uma segunda formação, a de intérprete, em um único bacharelado. Chama ainda mais atenção o fato de que, na FIBRA, mesmo não havendo disciplinas obrigatórias destinadas à interpretação, afirme-se formar intérpretes, tal como informado na denominação do bacharelado.

Ainda no que diz respeito às línguas de trabalho, tanto as IEs públicas quanto as IEs privadas destinam uma porcentagem reduzida ao estudo do português e uma carga horária substancialmente maior para o inglês. Tal fato chama atenção, pois, teoricamente, os futuros profissionais da Tradução deveriam traduzir principalmente de sua primeira língua estrangeira (inglês) para a sua língua materna (português). Essa realidade contradiz as recomendações de Valentine (1996) e confirma as constatações de Shäffner e Adab (2000) e Gonçalves e Machado (2006). Além disso, uma minoria tanto de IES públicas quanto privadas ofertam disciplinas obrigatórias destinadas ao estudo de uma segunda língua estrangeira, como defendido por Nord (2005a, 2005b).

Podemos perceber, contudo, que tanto as IES públicas quanto privadas, ao elaborarem a matriz curricular, convergem para uma única base: as Diretrizes Curriculares Nacionais para os cursos de Letras (Brasil, 2001). Essa afirmação é justificada pela porcentagem de carga horária obrigatória destinada aos estudos literárias e linguísticos. Poucos são os bacharelados que não ofertam disciplinas a eles relacionados. Podemos afirmar que tanto as IES públicas quanto as IES privadas não dão a devida importância ao estudo da literatura brasileira, dada sua baixa porcentagem de carga horária, o que demonstra mais uma vez o destaque concedido à língua estrangeira. Porém, ao comparar os bacharelados das IES públicas aos das IEs privadas, podemos ver uma diferença: mesmo dedicando à literatu- 
ra estrangeira uma carga horária obrigatória maior do que à literatura brasileira, é na IES privada que essa diferença é mais expressiva. Ainda no que diz respeito aos estudos literários, é nos bacharelados de IEs públicas que se faz maior a oferta de disciplinas obrigatórias destinadas ao estudo das Teorias Literária.

No que diz respeito às disciplinas obrigatórias de conteúdo profissionalizante, isto é, aquelas destinadas à Tradução, tanto teóricas quanto práticas, podemos perceber outra diferença significante: as disciplinas obrigatórias relativas às teorias da tradução ocupam uma carga horária maior nas IES públicas que nas IES privadas. Já no que diz respeito às disciplinas de prática de tradução, a carga horária pouco difere entre as IES públicas e privadas, o que põe em questão a crença de que nas IEs privadas há um foco maior na prática tradutória que não aconteceria nas IEs públicas.

Como exposto por Goodson (2013), os currículos devem ser constituídos por conhecimentos considerados válidos. Eles permitem contar a história de cada profissão, além de ressaltarem as diferentes tradições. Verificamos que os bacharelados destinados à formação de tradutoras e tradutores no Brasil ainda são influenciados pelo curso de Letras. Porém, com a criação de graduações desvinculadas deste curso, intitulados Bacharelado em Tradução, ofertadas pela UFPB e UFU, percebemos que uma nova tradição, que se distancia dos cursos de Letras, está sendo construída. Por fim, chamamos atenção para o fato de que poucos são os documentos de cada curso que apresentam seu entendimento quanto ao conceito de competência, quer seja competência do tradutor, quer seja competência tradutória. Tal como Kelly (2005), acreditamos que as concepções curriculares dos bacharelados em Tradução devem partir das necessidades sociais, bem como o mercado de trabalho, o que pode jus- tificar a criação de cursos no interior do país, por vezes longe do eixo Rio-São Paulo ${ }^{18}$.

Assim, há no Brasil diferentes tradições, no sentido amplo da palavra, quanto à formação de tradutoras e tradutores no Brasil. Essas tradições por vezes se aproximam, por exemplo, no que diz respeito à oferta de disciplinas obrigatórias relacionadas aos estudos literários e linguísticos, e por vezes se distanciam, por exemplo, quanto à oferta de disciplinas obrigatórias relacionadas ao conteúdo profissionalizante e mesmo à segunda formação, aquela de intérprete. Essa constatação nos faz questionar mais uma vez o porquê destas diferenças.

Possivelmente a resposta para esse questionamento está na regulamentação da profissão de tradutor e tradutor e/ou intérprete de línguas orais no Brasil. A profissão é reconhecida desde 1988, mas não é regulamentada. Essa ausência de regulamentação permite que indivíduos não graduados em Tradução atuem nessa atividade laboral. Além disso, não há a obrigatoriedade de que tradutoras e tradutores se credenciem no Sindicato Nacional de Tradutores (SINTRA) ou na Associação Brasileira de Tradutores e Intérpretes (ABRATES), pois tais entidades não atuam como Conselhos Federais e, consequentemente, não podem intervir junto ao Ministério da Educação para uma formação básica e uniforme. Essa falta de regulamentação influencia diretamente a concepção dos bacharelados em Tradução (Costa, 2018).

18 Poderíamos estender esse artigo ainda para questões políticas e econômicas que possivelmente influenciaram a criação de bacharelados em Letras-Tradução e Tradução em todas as regiões do Brasil, com diferentes concentrações. Contudo, o artigo se tornaria demasiadamente longo, razão pela qual sugerimos a leitura do capítulo 3 de Costa (2018). 


\section{Referências}

Bartrina, F. (2005). Theory and Translator Training. In M. Tennent (Ed.), Training for the New Millennium (pp. 177-189). Amsterdam/Philadelphia: John Benjamins Publishing Company.

Briks, F. J. P. (no prelo). O ensino de inglês para tradutores em formação: proposta de plano de ensino e amostra de material didático [Dissertação em Estudos da Tradução]. Florianópolis: Universidade Federal de Santa Catarina.

Cardozo, M. M. (2008). Uma proposta de Bacharelado Acadêmico em Estudos da Tradução: o modelo UFPR. In XXIII Encontro Nacional de Pós-Graduação e Pesquisa Em Letras e Linguística, 2008, Goiânia. Página eletrônica do GT de Tradução da Anpoll. UFMG, FALE: GTTRAD, (pp. 1-9). Disponível em: http://letra.letras.ufmg.br/gttrad/ enanpoll/2008/10\%20-\%20Uma $\% 20$ proposta $\% 20 \mathrm{de} \% 20$ Bacharelado $\% 20$ acad $\%$ C3\%AAmico $\% 20$ em $\% 20$ Estudos $\% 20$ da\%20Tradu\%C3\%A7ao.pdf. Acesso em: fevereiro 2019.

Cardozo, M. M. (2013). A institucionalização da tradução na UFPR: 2001-2011, dez anos do Bacharelado Acadêmico em Estudos da Tradução. In A. Guerini, M. C. Torres e W.C. Costa (Orgs.), Os Estudos da Tradução no Brasil nos séculos XX e XXI (pp. 101120). Tubarão, sc: Copiart; Florianópolis: PGET/UFSC.

CIUTI. Disponível em: http://www.ciuti.org/ fr/qui-sommes-nous/histoire/ Acesso em: novembro 2018.

Cohen, L., Manion, L. e Morrison, K. (Eds.) (2007). Research Methods in Education (6 ${ }^{\mathrm{a}}$. Ed). London: Routledge/Taylor \& Francis Group.

Costa, P. R. (2018). A formação de tradutores em instituições de educação superior públicas brasileiras: uma análise documental [Tese de doutorado em Estudos da Tradução]. Flo- rianópolis: Universidade Federal de Santa Catarina. Disponível em: https://repositorio.ufsc.br/handle/123456789/188094 Acesso em: fevereiro 2019.

Fiola, M. A. (2003). La notion de programme en didactique de la traduction professionnelle: le cas du Canada [Tese de doutorado em Tradutologia] Paris: Université Paris III - Sorbonne Nouvelle.

Frota, M. P. (2007). Um balanço dos Estudos da Tradução no Brasil. Cadernos de Tradução, 1 (19), 135-169. Disponível em: https://periodicos.ufsc.br/index.php/traducao/article/view/6996/6481 Acesso em: fevereiro 2019.

Frota, M. P., Britto, P. H. e Martins, M. A. P. (2012) Apresentação - Maria Candida Bordenave e a Tradução no Brasil. Tradução em Revista, 13(2), 1-6. Disponível em: https://www.maxwell.vrac.puc-rio. br/20913/20913.PDFXXvmi=. Acesso em: fevereiro 2019.

Gil, A. C. (2008). Como elaborar projetos de pesquisa (4. ed). São Paulo: Atlas.

Gonçalves, José Luiz V. R. (2015). Repensando o desenvolvimento da competência tradutória e suas implicações para a formação do tradutor. Revista Graphos (UFPB), João Pessoa, v. 17, n. 1, p. 114-130. Disponível em: http://periodicos.ufpb.br/ index.php/graphos/article/view/25053. Acesso em: fevereiro 2019.

Gonçalves, J. J. V. R. e Machado, I. T. N. (2006). Um panorama do ensino de Tradução e a busca da competência tradutória. Cadernos de Tradução, 1(17), 45-69. Disponível em: http://www.periodicos.ufsc.br/index. $\mathrm{php} /$ traducao/article/view/6856/6408. Acesso em: fevereiro 2019.

González-Davies, M. (2004) Undergraduate and postgraduate translation degrees. Aims and expectations. In K. Malmkjær (Ed.), Translation in Undergraduate Degree Programmes (pp. 67-81). Amsterdam/ 
Philadelphia: John Benjamins Publishing Company.

Goodson, I. F. (2013). Currículo: teoria e história. (A. Brunetta, trad. Revisão da tradução de H. Francischetti) (14. ed.). Petrópolis, RJ: Vozes.

Hagel, I. C. de (1990). Introducción. Meta, 35(3), 467-469. Disponível em: https:// www.erudit.org/fr/revues/meta/1990-v35-n3-meta329/002995ar/ Acesso em: fevereiro 2019.

Harris, B. (1997). Translation and Interpreting Schools. Amsterdam/Philadelphia: John Benjamins.

Kelly, D. (2005). A Handbook for Translator Trainers. Manchester: St. Jerome Publishing.

Kelly, D. e Martin, A. (2009). Training and Education. In M. Baker e G. Saldanha (Eds.). Routledge Encyclopedia of Translation Studies ( $2^{\text {nd }}$ ed, pp. 294-300). London; New York: Routledge.

Lei $\mathrm{n}^{\circ} 5.540$, de 28 de novembro de 1968. Fixa normas de organização e funcionamento do ensino superior e sua articulação com a escola média, e dá outras providências. Brasília, Diário Oficial, 23 nov. 1968. Disponível em: http://www2.camara.leg.br/ legin/fed/lei/1960-1969/lei-5540-28-novembro-1968-359201-publicacaooriginal-1-pl.html Acesso em: fevereiro 2019.

Lamoureux, A. (2003). Recherche et méthodologie en Sciences Humaines ( $2^{\mathrm{e}}$ éd). Laval, Canadá: Éditions Études Vivantes.

Ministério da Educação e do Desporto (1997). Conselho Nacional de Educação. Parecer CNE $n^{\circ}$ 776/97, Brasília, 03 de dezembro de 1997. Orienta para as diretrizes curriculares dos cursos de graduação. Disponível em: http://portal.mec.gov.br/setec/ arquivos/pdf/PCNE776_97.pdf. Acesso em: fevereiro 2019.

Ministério da Educação (2015). Nota técnica $n^{\circ}$ 793/2015-CGLNRS/DPR/SERES/MEC. Disponível em: http://www.consultaesic.
cgu.gov.br/busca/dados/Lists/Pedido/ Attachments/513726/RESPOSTA_PEDIDO_NT_793_2015.pdf. Acesso em: novembro 2018.

Ministério da Educação. Conselho Nacional de Educação (2001). Parecer CNE/ CES 492, de 03 de abril de 2001. Diretrizes Curriculares Nacionais dos cursos de Filosofia, História, Geografia, Serviço Social, Comunicação Social, Ciências Sociais, Letras, Biblioteconomia, Arquivologia e Museologia. Diário Oficial. Disponível em: http://portal.mec.gov.br/cne/ arquivos/pdf/CES0492.pdf. Acesso em: fevereiro 2019.

Ministério da Educação. Conselho Nacional de Educação (2002). Parecer CNE/CES 1363, de 12 de dezembro de 2001. Retificação do Parecer CNE/CES 492/2001, que trata da aprovação das Diretrizes Curriculares Nacionais dos Cursos de Filosofia, História, Geografia, Serviço Social, Comunicação Social, Ciências Sociais, Letras, Biblioteconomia, Arquivologia e Museologia. Diário Oficial, 29 jan. Disponível em: http://portal.mec.gov.br/ cne/arquivos/pdf/2001/pces1363_01. pdf. Acesso em: fevereiro 2019.

Ministério da Educação. Conselho Nacional de Educação (2007). Despacho do Ministro, publicado no Diário Oficial da União de 24/09/2007. Disponível em: http://portal.mec.gov.br/cne/arquivos/ pdf/2007/pces083_07.pdf Acesso em: fevereiro 2019.

Nord, C. (1991). Text Analysis in Translation: theory, methodology, and didactic application of a model of translation-oriented text analysis. (C. Nord e P. Sparrow, trads.). Amsterdam, Atlanta: Rodopi.

Nord, C. (2005a). All New on the European Front? What the Bologna Process Means for Translator Training in Germany. Meta, 50(1), 210-222. doi:10.7202/010669ar 
Nord, C. (2005b). Training functional translators. In M. Tennent (ed.), Training for the New Millenium. Amsterdam/Philadelphia: John Benjamins Publishing Company.

Palma Filho, J.C. (2010). A educação brasileira no período 1960-2000: de JK a FHC. Caderno de formação: formação de professores-educação cultura e desenvolvimento-História da Educação. Disponível em: http://www.acervodigital.unesp.br/handle/123456789/108 Acesso em: fevereiro 2019.

Paschoal, S. (2007). Pressupostos para a formação e a atuação do tradutor. Fragmentos: Revista de Língua e Literatura Estrangeiras, 33, 215-228. Disponível em: https:// periodicos.ufsc.br/index.php/fragmentos/article/view/8665/8006 Acesso em: fevereiro 2019.

Pym, A. (1998). Method in Translation History. Manchester, Reino Unido: St. Jerome Publishing.

Scott, J. (Ed.). (2006). Documentary ResearchK (vol. 1). London: Sage Publications.

Schäffner, C. e Adab, B. (Eds.) (2000). Developing translation competence. Amsterdam: John Benjamins.
Souza, J.V. de (2016). Educação Superior: evolução, organização e cenários. In M.Z.B. Rocha e N.M. Pimentel (Orgs.), Organização da Educação brasileira: marcos contemporâneos (pp. 349-388). Brasília: Editora UnB.

Thouin, M. (2014). Réaliser une recherche en didactique. Montréal, Canadá: Éditons MultiMondes.

UNESCO (1976). Recommandation sur la protection juridique des traducteurs et des traductions et sur les moyens pratiques d'améliorer la condition des traducteurs. Nairobi, Quênia. Disponível em http://portal.unesco. org/fr/ev.php-URL_ID $=13089 \& U R L \_D O=-$ DO_TOPIC\&URL_SECTION=201.html Acesso em: fevereiro 2019.

Valentine, E. (1996). Traductologie, traduction et formation: vers une modélisation de la formation en traduction - l'expérience canadienne [Tese (Doutorado em Linguística)]. Montréal, Canadá: Université de Montréal.

Venuti, L. (2017). Introduction - Translation, Interpretation and the Humanities. In Teaching Translation - Programs, Courses, Pedagogies (pp. 1-14). New York: Routledge.

Cómo citar este artículo: Costa, P. R., Guerini, A. y Pereira, G. H. (2019). A formação de tradutoras e tradutores de línguas orais (Português/Inglês) no Brasil: um estudo das diferentes concepções curriculares. Mutatis Mutandis. Revista Latinoamericana de Traducción, 12(1), 51-77. Dor: https://doi.org/10.17533/udea. mut.v12n1a02 